Portland State University

PDXScholar

1983

\title{
Teaching visual awareness to general education students
}

Larry Edward Gross

Portland State University

Follow this and additional works at: https://pdxscholar.library.pdx.edu/open_access_etds

Part of the Art Education Commons, and the Educational Methods Commons Let us know how access to this document benefits you.

\section{Recommended Citation}

Gross, Larry Edward, "Teaching visual awareness to general education students" (1983). Dissertations and Theses. Paper 3259.

https://doi.org/10.15760/etd.3250

This Thesis is brought to you for free and open access. It has been accepted for inclusion in Dissertations and Theses by an authorized administrator of PDXScholar. Please contact us if we can make this document more accessible: pdxscholar@pdx.edu. 
AN ABSTRACT OF THE THESIS OF Larry Edward Gross for the Master of Science in Teaching in Art presented June 1, 1983.

Title: Teaching Visual Awareness to General Education Students. APPROVED BY MEMBERS OF THE THESIS COMMITTEE:

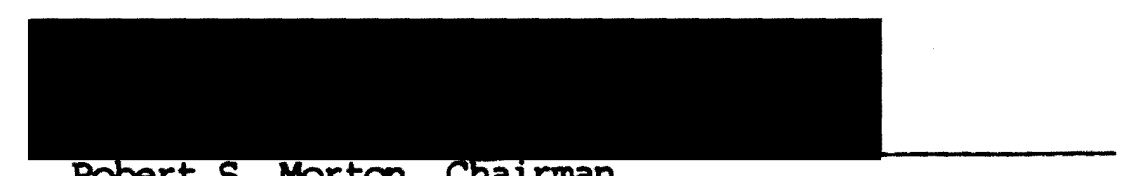

Robert S. Morton, Chairman
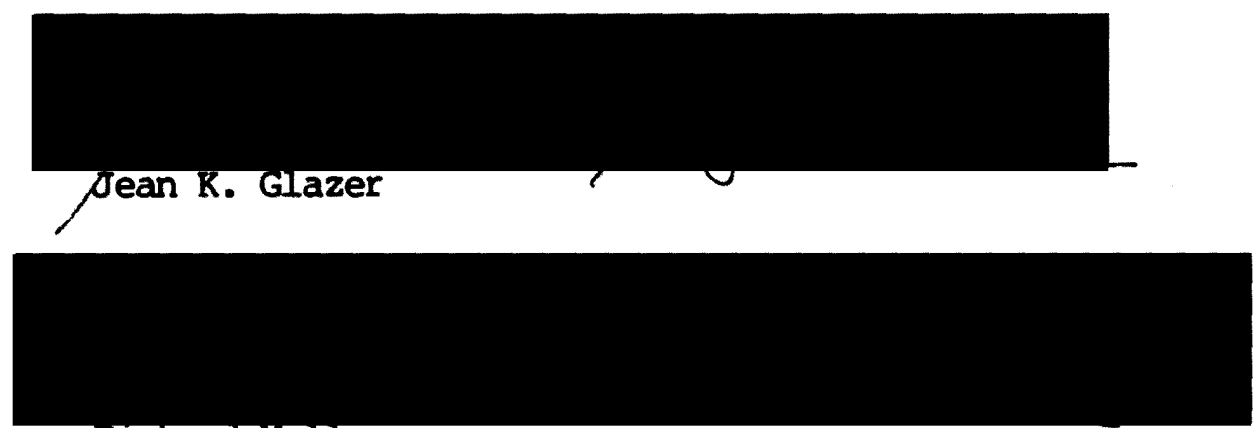

Richard Muner

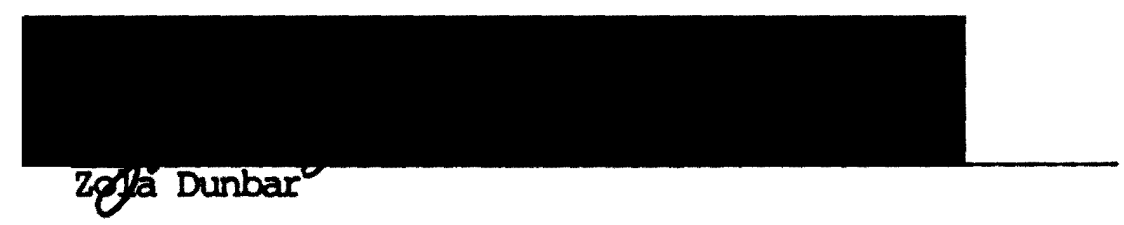

The goal of this thesis was to present a teaching method which would demonstrate increased visual awareness in general education college students. The particular approach presented for that purpose was also designed to be of potential benefit to students' total educational experience. To that end some conditions and specific research were introduced as necessary considerations for the teaching approach and for the role of art education as it pertains to the thesis goal. 
The first of these influences describes the specific situation, out of which the thesis content evolved. This means that the small size of Conoordia College (Portland, Oregon), its limited art program and facilities, and the type of student being taught provided the context and a rationale for the kind of art education curriculum proposed. The contents of this thesis was intended only as a part of that curriculum, since the time available for research and presentation was limited.

Recent research about human brain function also influenced the teaching approach, meaning that art could be seen as integral to the nature and function of the educational process. These insights, while interesting, were not meant as material to be proven rather as background for some of the visual exercises presented to students.

The proposed format for the teaching approach includes a series of practical art exercises which were divided into two groups. Each group emphasized one of two components needful in art education; visual awareness includes the learning of 1) visual organizational skills and 2) creative ideation. It was suggested that these be taught in the order written, although the two components are not really separable. The first group consisted of eight exercises (or visual problems) each one progressively more challenging than the previous one. In these exercises students' visual vocabulary improved as they developed their visual organizational skills. Each of the two exercises in the second group emphasized the creative ideational process by interrelating art with another subject. The interdisciplinary method used in these exercises resulted from the brain research, mentioned above, and a concern for the function of art 
in general education situations. One exercise involved conceptual relationships between art and science and the other related art and language as a means for learning more about the creative process.

All the exercises were presented to 16 students (as a part of a Basic Design course). Eleven of these students are represented in the thesis illustrations. As a part of the evaluation procedure, each student wrote a description of how they developed each art problem given. Many of these corments were of considerable value for interpretation and for support of the thesis itself. Examples of student art works, illustrated in the thesis, also give evidence of their achievement. In general, the students responded positively to the kinds of exercises, the teaching method, and to its applicability for their total education. Though this thesis is only one of many possible approaches to teaching visual awareness, it is apparently a valid one. 
TEACHING VISUAL AWARENESS TO GENERAL EDUCATION STUDENIS

by

IARRY EWWARD GROSS

A thesis submitted in partial fulfillment of the requirements for the degree of

MASTER OF SCIENCE IN TEACHING

in

ART

Portland State University

1983 
TO THE OFFICE OF GRADUATE STUDIES AND RESEARCH:

The members of the Committee approve the thesis of Larry Edward Gross presented June 1, 1983.

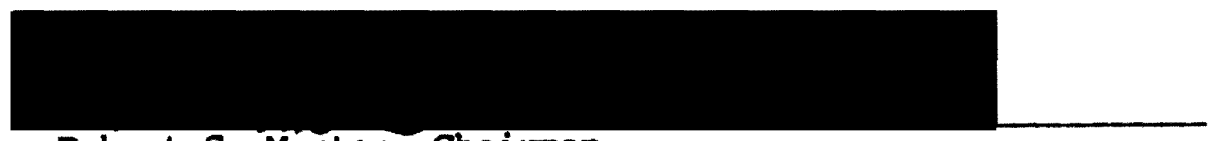

Robert S. Morton, Chairman
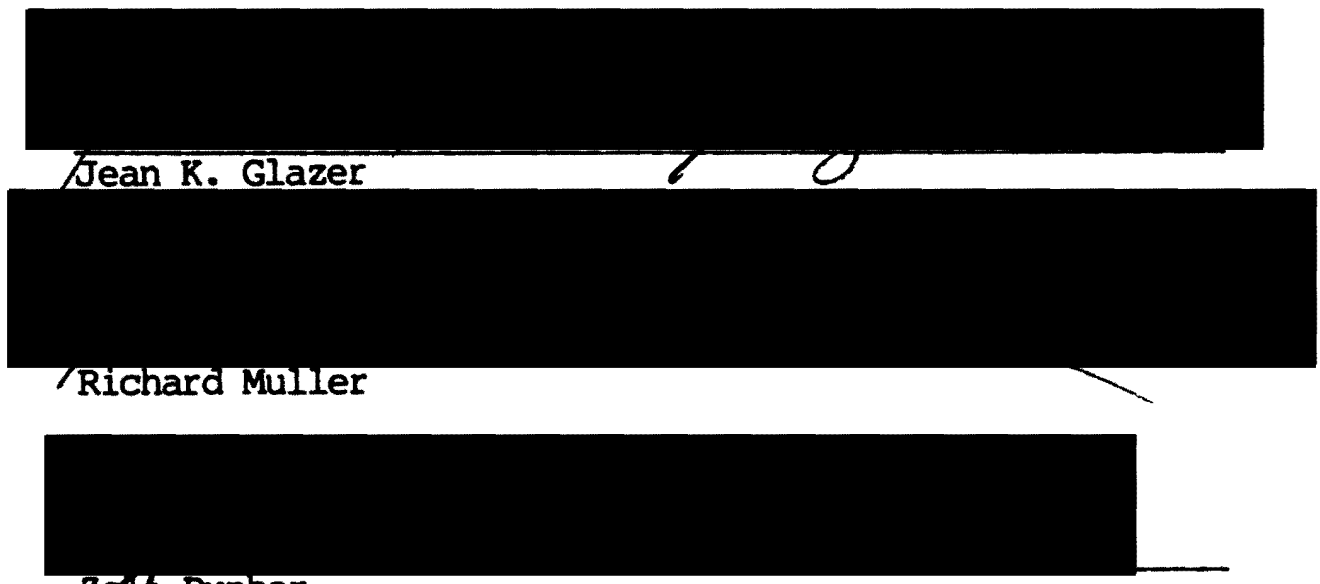

Zqua Dunbar

APPROVED:

Leonafd B. Kimbrell, Head, Department of Art and Architecture

Stanley E. Rauch, Dean of Graduate Studies and Research 


\section{ACKNOWIEDGEMENIS}

Several people deserve same recognition for their contributions to this thesis. Thanks to Professor Robert Morton, chairman of the advising committee, for his patience and composure with me when the work got difficult and his commitment was taxed.

The Concordia college computer services deserves recognition, especially its director, Eddie Balfour, who gave time and advice while the thesis was being prepared on Concordia's computer equipment.

I am especially thankful to my colleague, Professor Johnnie Driessner, whose undying enthusiasm for and support of my thesis was inspirational. He also gave considerable assistance on the college computer .

Finally, I am most grateful to my wife, Theresa, and my daughters, Alicia and Anna, who had to live with me through this endeavor. Also, to Theresa for her typing expertise, without which I might still be druming on the computer terminal. 
TABIE OF CONIENIS

PAGE

ACKNOWLEDGOMENTS . . . . . . . . . . . . . . . . . iii LIST OF FIGURES . . . . . . . . . . . . . . . . . . vi CHAPTER

I INIRODUCTION: CONDITIONS AND RESEARCH AFFECTING THE TEACHING APPROACH . . . . . . . . . 1

II THE PERTINENCE OF ART TO EDUCATION . . . . . . . . . 7

The Nature of Art and the Design Process . . . . . 8

Approaches to Art Education . . . . . . . . 12

III TEACHING VISUAL ORGANIZATIONAL SKILLS

(GROUP A EXERCISES) • . . . . . . . . . . . 17

Exercise 1... . . . . . . . . . 19

Exercise 2. . . . . . . . . . . . 20

Exercise 3 . . . . . . . . . . . 24

Exercise 4.................... 24

Exercise 5... . . . . . . . . . . 28

Exercise 6 . . . . . . . . . . . 31

Exercise 7... . . . . . . . . . 32

Exercise 8 . . . . . . . . . . . . 34

IV ITNKING ART AND OTHER SUBJECTS

(GROUP B EXERCISES) . . . . . . . . . . 38

Exercise 9 - Art and Science . . . . . . . 38

Exercise 10 - Art and Language . . . . . . . . 52 
CHAPTER

PAGE

v conclustans . . . . . . . . . . . . . . . 60

SOURCES CONSULTED . . . . . . . . . . . . . . . . . 63 


\section{LIST OF FIGURES}

FIGURE

PAGE

1. Organization studies (Exercise 1) ......... 22

2. Rhythmic pattern study (Exercise 2) . . . . . . 22

3. Rhythmic pattern study (Exercise 2) ........ 23

4. Rhythmic pattern study (Exercise 2) ........ 23

5. Motion study (Exercise 3) . . . . . . . . . 25

6. Motion study (Exercise 3) ............ 25

7. Motion study (Exercise 3) . . . . . . . . . 25

8. Rhythm studies (Exercise 4) . . . . . . . . 27

9. Rhythm studies (Exercise 4) . . . . . . . . 27

10. Texture study (Exercise 5) ........... 30

11. Texture study (Exercise 5) . . . . . . . . 30

12. Student's personal study ............. 30

13. Letter forms study (Exercise 6) . . . . . . . . 33

14. Letter forms study (Exercise 6) . . . . . . . . 33

15. Fragmented letter forms (Exercise 7) . . . . . 35

16. Fragmented letter forms (Exercise 7) . . . . . 35

17. Fragmented letter forms (Exercise 7) . . . . . 35

18. Fragmented letter forms (Exercise 7) ........ 35

19. Visual/Verbal study (Exercise 8) .......... 36

20. Visual/Nerbal study (Exercise 8) . . . . . . . 36

21. Concordia art room (Exercise 9) ............ 44

22. "Analytic" process (Exercise 9) ............ 44

23. "Analytic" process (Exercise 9) .......... 45 
24. Value progression - "Analytic" process (Exercise 9) . . . 45

25. Analysis to synthesis by M. (Exercise 9) . . . . . 4 47

26. Analysis to synthesis by C. (Exercise 9) . . . . . . 47

27. Analysis to synthesis by J. (Exercise 9) . . . . . . 48

28. Finished "synthesis" by B. (Exercise 9) . . . . . . 4 49

29. Finished "synthesis" by L. (Exercise 9) . . . . . . . 49

30. Finished "synthesis" by D. (Exercise 9) . . . . . . 50

31. Finished "synthesis" by J. (Exercise 9) . . . . . . 50

32. Visual/Verbal illustration by author ........ 56

33. "Magnify" interpreted by S. (Exercise 10) . . . . . 56

34. "Magnify/Minify" interpreted by C. (Exercise 10) . . . 56

35. "Adapt" interpreted by M. (Exercise 10) ........ 58

36. "Adapt" interpreted by J. (Exercise 10) . . . . . . 58 


\section{CHAPTER I}

\section{INTRODUCTION: CONDITIONS AND RESEARCH \\ AFFECTING THE TEACHING APPROACH}

Today's art educators must be sensitive to an ever-more-complex society which affects the making of art and thus the content of art educational curricula. As the variety and availability of art increases, the meaning of art changes, and, while some may regard this as healthy and natural, it has often been misunderstood, especially by the general public who may lack experience with the art process. It is owing to this lack of experience that art educators must determine what are the essential ingredients of a meaningful art curriculum.

The primary goal of this thesis was to identify and develop an effective method of teaching visual awareness to general education college students. One of the more significant factors contributing to this formulation concerns the unique situation, that is, the students, the art facility, and the place, around which the thesis developed. I an the only full-time art instructor at Concordia college in Portland, Oregon, which has a total student enrollment currently fluctuating around 375. During my five years of employment, Concordia's status has grown from a two-year junior college to a four-year, fully accredited liberal arts college. With this change came the realization that students would be graduating from concordia and embarking on a lifetime with only limited art experience. This affected my perceptions regarding the role of art education within this very unique place.

Concordia offers only a limited variety of introductory art 
courses. Because of Conoordia's size and its limited art offerings and facilities-a single roan is supposed to service all the studio art courses-one can hardly compare it with most other college level art: departments. This situation presented considerable difficulty in locating appropriate resource material, especially that which addresses art education at the small college, non-major level. In my own mind, I have compared concordia's introductory art courses to secondary school level art courses, the only significant difference being the maturity-level of students. The majority of students who enroll in these art courses are not - and have no intention of becoming - art majors. Many have had no classroom art experience since their junior high education and enroll only because it is a general education requirement. Recognizing these limitations was a necessary element in my search to develop an art curriculum at Concordia which would be aesthetically meaningful, non-threatening to the inexperienced, and ideologically useful to students preparing for responsible positions in society.

Another factor contributing to the thesis formulation deserves some introductory attention. Current research about the brain and its functions has introduced some interesting insights regarding the nature and function of the educational process. While it is not my intent to prove any of the theories, I was interested in using some of the ideas as a means of enriching and improving students' visual awareness. The authors of The Wholeschool Book suggest that those who go "through the highly rational experience of getting a degree in college [tend] to 
forget a whole arena of mind function that helps to keep us alive." The "arena" to which the authors refer includes, among other things, the abilities of visualization, of perceiving things spatially, and of synthesizing many parts into new wholes. (2) While all of these qualities have commonly been associated with and expected of artists (and those who teach art), these are not the exclusive "property" of artists. The research indicates that everyone has the capacity to develop these abilities. (3) More will be said later about the pertinence of this research to the thesis. Meanwhile, it is important to acknowledge that the research is causing educators to consider the role of the mind in the educational process, and thus its implications for teaching methods.

Martin Engel suggests the need to identify "a new vocabulary and a different attitude about what constitutes instruction in the arts and how that is to be conducted." (4) It was this attitude toward new teaching approaches which made me consider the possibility that art can be taught as an integral part of other subjects. While the method I developed for this purpose might be unique, the idea is not. Several

(1) Bob Samples, et. al., The Wholeschool Book (Reading, Massachusetts: Addison-Wesley Pub. Co., 1977) p. 10.

(2) Betty Edwards, Drawing on the Right Side of the Brain (Los Angeles: J.P. Tarcher, Inc., 1979) P. 40.

(3) Bob Samples, The Metaphoric Mind (Reading, Massachusetts: Addison-Wesley Pub. Co., 1976) pp. 16-26.

(4) Martin Engel, "Art and the Mind," Art Education, Vol. 36, No. 2 (March 1983) p. 6. 
educators and writers have addressed the issue. When Viktor Lowenfeld asserted that the senses are basic to man's learning, (5) he implied that the senses are integral to perceptions, to thoughts, and thus to learning. A detailed description of this is forthooming. Herbert Read took it a step further by insisting that "art should be the basis of education." (6) Furthermore, he wrote,

those activities which we denote by such words as 'imaginative', 'creative', 'originating', 'aesthetic', do not represent a subject with definite limits which can be treated like any other subject and allotted its two or five or seven periods in a competitive time-table, but rather an aspect of mental development which is all-embracing.... (7)

Perhaps the indefinite nature of the creative process has led to some of the misunderstandings about art referred to earlier. Naturally, this dilerma is only heightened when many artists openly express difficulty in describing their art and the processes out of which it evolves. So, it was important to determine how best to cormunicate to students the role of discovery in the creative process. The following argument served as a positive element toward that end.

(5) Viktor Lowenfeld, and Lambert $w$. Brittain, Creative and Mental Growth, 6th ed. (New York: Macmillan Pub. Co., Inc., 1975), pp. 5 and 12 .

(6) Herbert Read, Education Through Art, 3rd ed. (New York: Random House, 1958), p. 1 .

(7) Ibid., p. 220. 
Many people believe that "discovery" is actually an act of creation. If this is so, then the distinction between scientists, poets, painters and writers is not clear. In fact, it is possible that scientists, poets, painters and writers are all members of the same family of people whose gift it is by nature to take those things which we call commonplace and to re-present them to us in such ways that our self-imposed limitations are expanded. (8)

Consequently, it was my recognition that art is not co-equal with, but inseparable from all other disciplines, (9) which led me to the core of the thesis. It is my goal to demonstrate that post-secondary students, who are marginally acquainted with visual organizational skills, will gain increased visual awareness when they identify and respond to interrelationships between art and other academic disciplines.

In order to address both parts of this goal statement it was necessary to divide the material into two sections. The first section includes a group of exercises designed to give students practical experience with organization skills, and in so doing prepare them for the exercises in the second section. This section includes visual problems designed to promote relationships between art and other subjects as a means of increasing students' visual awareness.

(8) Gary Zukav, The Dancing Wu Li Masters (New York: Bantam Books, 1979), pp. 9-10.

(9) C.H. Waddington, Behind Appearance: A Study of the Relations Between Painting and the Natural Sciences in This Century (Edinburgh: University Press, 1969), p. 10. 
The cambined groups of exercises are intended to be practical art experience for developing both the technical skill and the creative perception of students. "Today's college students... are eager to participate in the creative act to whatever extent they are capable," (10) It was also my hope that the studio experience would heighten the students' ability "for new and personally achieved solution in other academic areas," (11) especially during their college career. The purpose of chapter two will be to inform the reader of thoughts and research which aided in the fabrication of the thesis.

(10) The Open Eye in Learning: The Role of Art in General Education, Richard Bassett, ed. (Cambridge, Mass., The MIT Press, 1969) p. 100.

(11) Ibid., p. 105. 


\section{THE PERTINENCE OF ART TO EDUCATION}

One of the basic premises which contributes to the planning of art curricula is the concern that we are living in the environment of a highly specialized culture. The fragmentation and separation which results from this specialization has had an effect on the structural make-up of education. This can be seen especially in secondary and post-secondary school programs where schedules are fixed and students receive instruction from several "specialized" people. While specialization is desirable, if not necessary, for students preparing for professional art careers, it is unrealistic and impractical for those to whom this thesis is addressed. I am frequently confronted by students in the latter category, who are both surprised and delighted when they come to an aesthetic awareness never before considered.

It was partially a reaction against specialization which caused the "Open classroom" experiments in education during the 1960's. (12) And while it is not the place of this thesis to argue in support of this approach, I an not surprised when art educators scoff at more current concerns to go "back to basics," especially when research indicates the need to balance learning experiences of the brain's left and right hemispheres. More will be said about this later, however, "in an age when the fragmentation of knowledge is most pronounced, the

(12) Samples, et. al. The Wholeschool Book, pp. 113-132. 
greatest need might be a device through which to see things whole." (13) This thesis contends that art can be this "device." This section of the thesis deals with the nature of art and perception, in which it might be seen how art can contribute to wholeness in students' educational experience.

THE NATURE OF ART AND THE DESIGN PROCESS

"Making decisions and choices constitutes a real problem in the lives of many people." (14) It is possible that the selection and decision-making inherent in the art activity, when extensively practiced, increases the capacity to solve problems creatively in other life situations. (15) This is understood through a closer look at the nature of art and the mental processes which accompany the design process. If we accept what Lowenfeld said regarding the role of the senses in learning, we can see the intrinsic place of art in the learning, thinking process, because the senses play a direct role in the formulation of a concept.

Concepts are the mental structures, the thoughts, ideas, images, and schemas. Perceptions are conceptually mediated sensations. The sensations are the signals received by the

(13) The Open Eye in Learning, p. 78.

(14) Manfred Keiler, The Art in Teaching Art (Lincoln, Nebraska: University of Nebraska Press, 1961), p. 42.

(15) Ibid., p. 42. 
sensorium, the sense receptors. Through perceptions, the mind controls what we receive in our minds from our sensorium. (16)

Stated in simplified terms, this means that perceptions affect and are affected by thoughts. Rudolf Arnheim foresaw these ideas when he pioneered the concept of "visual thinking." The following is a recent application of his assertion that "visual thinking is constantly used by everyone." (17)

The three fundamentals of education are perceiving, thinking, forming [and] there is no perceiving without thinking and forming, no thinking without perceiving and forming, and no forming without perceiving and thinking. Together they are the three aspects of the productive mind and as one trains one of them, one always trains all three. (18)

If this is true then the mental processes involved in doing art coexist with and relate to mental processes involved in, say, a physics problem; indeed, "images were a functional ingredient in Sir Isaac Newton's thinking." (19) Accordingly, processing images in the mind, or, imagination, is used in every field of knowledge, and is therefore an important link between the disciplines. Since the arts are

(16) Engel, p. 7.

(17) Rudolf Arnheim, "Perceiving, Thinking, Forming." Art Education, Vol. 36, No. 2 (March, 1983), p. 10.

(18) loc.cit., p. 10.

(19) Read, p. 53. 
excellent for learning visual relationships, they are "the medium of choice for training in what one might call the syntax of relations." (20) This argument adds credence to the idea that art is intrinsically related to other disciplines, which supplied the context for the exercises presented in chapter 4.

Ideas from other disciplines were useful when teaching the cognitive aspects of creative expression. One such idea is currently receiving attention in the sciences. It is the notion that "everything is connected to everything." (21) This thought is apparent to me, sometimes, when I observe things in nature and in human activity. I have developed a series of color slides including images which illustrate my personal interpretation of this idea. A brief description of these slides may be useful to the reader. The slides illustrate distinct visual relationships between several uniquely different objects. (These are called visual metaphors.) I see comparisons, for example between the blood veins in our circulatory system and the pattern of lines created by a river and its tributaries (as seen from above). The same basic pattern of lines appears in trees, in freeway systems, and in many other things which grow and change. Seeing these relationships has caused me often to ponder the thought

(20) Arnheim, p. 10.

(21) Barry Commoner, The Closing Circle (New York: Bantam Books, 1971), p. $29 f$. 
that everything is related to everything else. The apparent design which orders the universe seems to reflect the definition of design, which is "the organization of parts into a coherent whole." (22)

The right-hemispheric brain function of seeking relationships is one of the ways to accomplish this organization, and as one continues to find visual relationships, the notion of science seems also a notion of art. Consequently, seeking relationships between art and other subjects could be understood as both a rationale and a means for creative expression.

In my own experience the process of discovery is usually accompanied by a sense of awe, shortly followed by a certain feeling that "I should have known it before." The following two thoughts, strikingly similar, come from different fields. Bevlin described the design process as being "both conscious and unconscious," (23) whereas Nietzche said that "every extension of knowledge arises from making conscious the unconscious." (24) The latter seems to imply that all knowledge already exists, an idea currently receiving attention in the physical sciences, one which offers insight regarding the relationship

(22) Marjorie Elliot Bevlin, Design Through Discovery, brief ed. (New York: Holt, Reinhart and Winston, 1980), p. 2.

(23) Ibid., p. 30.

(24) Robert H. McKim, Experiences in Visual Thinking, (Belmont, CA: Wadsworth Pub. Co., 1972), p. 21. 
between artists, scientists, poets, and writers. All are engaged in a process of discovering the same thing: knowledge. From the standpoint of science this knowledge is referred to as "truth-about" the subject matter, while in art it is referred to as "truth-to" the same subject matter. (25) This seems to place the realm of art on a multi-directional level, supplying, perhaps, the reason why some people believe there is an artist in everyone, designing, arranging, and discovering how best to respond to life's challenges. Although these illustrations may not aid students in the actual art activity, an awareness of them offers a more complete understanding of how ideas develop, sometimes seemingly out of nowhere, during the design process. In other words, it might be said that the relationships are there to discover. This thought can be liberating to general education students who respond nervously to vague rules of art and to infrequent opportunities (at least in academic settings) for personal expression.

\section{APPROACHES TO ART EDUCATION}

There are basically two opposite, but not opposing, kinds of education: that which "amasses skill", as was done in the apprentice schools, and that which "cultivates motive", the creative urge. (26)

(25) Harold Cassidy, The Sciences and the Arts: A New Alliance (New York: Harper and Brothers, 1962), p. 19.

(26) The Open Eye in Learning, p. 196. 
The latter has gained more attention in the past several decades, when "conformity to rigid standards was abandoned." (27) Although "art is the perfect marriage of psychic impulse and technical implementation," (28) the visual exercises for this thesis were divided into two groups, each group favoring a different approach. The material in chapter three was presented with the "skills" approach so that students would feel more confident when responding to the material in chapter four, favoring the second - referred to here as the "motives" - approach. The aim was to provide an atmosphere which might help students to transfer their visual "skills" and creative "motives" to other subjects and to their everyday life, in general. These different approaches to art education were the bases for two groups of exercises presented in chapters three and four.

It is interesting to compare these approaches to the cerebral activities of intellect and intuition. The intellect correlates with the "skills" approach and intuition is comparable to the "motives" approach. Perhaps this correlation is more meaningful if explained in the context of some brain research, which was mentioned earlier. According to the research, the left hemisphere of the brain "in most of us in our society" is primarily responsible for those activities which

(27) Keiler, p. 40.

(28) Jose Argüelles, The Transformative Vision (Boulder, $\infty$ : Shambhala Publications, 1975), p. 4. 
are linear, logical and sequential in nature. "This is the 'orderly', 'tidy' and in same ways 'conventional' half of our brain." (29) Stated in an over-simplified way, then, the attitude associated with this hemisphere is comparable to the "skills" approach, an attitude which seems to have dominated the French Academies producing artists such as David and Ingres. Conversely, the right hemisphere of the brain - in addition to the abilities mentioned earlier - "has tremendous inventive capacities... sees things in pictures, senses them fully, and frequently manages to slip past the censoring voice of the rational left hemisphere to make its 'knowings' known." (30) Again, over-simplified, these attributes are comparable to the "motives" approach of art education and related to the attitude which caused the Impressionists, Monet, Renoir, and others, to act against the traditions of the academies.

Fortunately, the two hemispheres are connected, otherwise it might be impossible to apply both teaching approaches simultaneously. The connecting tissue between hemispheres is called the corpus callosum, which apparently makes "communication" between the two hemispheres possible. (31) All of this is stated in rather simplified terms, but it sheds light on how intellect and intuition can operate

(29) Bob Samples, et. al. The Wholeschool Book, p. 48.

(30) Ibid., p. 49.

(31) Edwards, p. 28. 
together in the creative process. And if we accept the definition of art given above we can understand that it is important to balance the "skills" and the "motives" approaches. It should be reiterated that this explanation is not offered as a mandate for including the arts in education so much as one possible means for students to gain an understanding of and facility with the art process.

Actually the brain theory has brought about a potential weakness when applied to education by art teachers who use it as an excuse to give equal time to the arts. These subjects are generally attributed to the right hemisphere. The rationale for this argument grows out of a reaction against the traditional approach to education, which has given greatest attention to reading, writing and arithmetic, subjects attributed to one, the left, hemisphere. But taking the "equal time" attitude can also add to the dilerma of specialization and fragmentation mentioned earlier. On the other hand, if the research is right and educators take it seriously, then we should be seeking methods which will integrate the two hemispheres.

Madeline Hunter strongly asserted how educators should respond to "all of these interesting findings." She says that the findings "clearly mandate" the responsibility of presenting instruction so that, whenever possible, information that is presented in linear fashion across time (reading it or hearing it), should also be presented in visual space (seeing or visualizing it), so students have "practice in 
integrating the information in their two hemispheres." (32) The content of this statement deserves, perhaps, another thesis in itself, nevertheless, I considered her statement as an applicable pretense for my project. The format I am proposing is one way to approach the balancing of hemispheres as she describes. At this point, enough background material has been established for a clearer understanding of the manner I used in presenting the visual exercises.

(32) Madeline Hunter, "Right-Brained Kids in Left-Brained Schools," Today's Education, Vol. 65, No. 4 (Nov.-Dec. 1976) p. 48. 
CHAPTER III

\section{TEACHING VISUAL ORGANIZATIONAL SRILLS (GROUP A EXERCISES)}

Before describing each exercise in this chapter, it is necessary to explain what were the arrangements and the evaluation methods used.

The exercises documented in this thesis were selected from problems presented to 16 students in a Basic Design Course. As such they are considered to be the most suitable - in light of my goal of all those presented during the ten week course. The title of the course partially accounts for the considerable attention which has been given to the design process. Also, an understanding of the creative process is essential if students' visual awareness is to be increased. (33) As explained earlier, the thesis is divided into two groups of exercises. These will be referred to fram now on as group A, exercises in this chapter, which attempt to emphasize the "skills" part of art, and group B, those in the next chapter, which attempt to emphasize the "motives" part. Due to the nature of this sequence and the limited time factor (a 10-week course), only certain elements of design were emphasized: line, shape, value, and texture, but particularly shape in group A exercises. (A few ideas for additional exercises are included for the benefit of readers who might be interested in adopting this sequence for art instruction. However, the thesis is not intended as a comprehensive study of design elements.)

(33) Keiler, p. 18. 
Visual skills are taught effectively when assignments are accompanied by limitations and guidelines, which are intended to evoke an attitude of inquiry and inventiveness.

of the two powerful instincts which exist in all humans, and which can be used in teaching, says Gilbert Highet, one is the love of play. 'The Renaissance teachers, instead of beating their pupils, spurred them on by a number of appeals to the play-principle.' They made games out of the chore of learning difficult subjects ... Depending on the nature of the problem, some or all of the psychological and intellectual factors implicit in game-playing are equally implicit in successful problem-solving... Without the basic rules or disciplines, however, there is no motivation, test of skill, or ultimate reward - in short, no game. (34)

This method was used, whenever possible, in order to enrich the students' development of a visual vocabulary, while contributing to their sense of accomplishment, another factor in effective teaching. Each problem in the sequence is progressively more difficult as the number of variables increases.

Five criteria were considered when evaluating all the exercises, some being emphasized more than others, depending on the intended emphasis of each group of exercises. Those criteria which relate to skills, for instance, were emphasized during the presentation and evaluation of group A problems. The other criteria, of course,

(34) Paul Rand, "Design and the Play Instinct," Education of Vision, edited by Gyorgy Kepes (New York: George Braziller, Inc., 1965), p. 156. 
received more attention in group B. It was important, however, to consider all criteria for each problem, since the distinction between "skills" and "motives" is not wholly clear, nor should they be taught completely apart fram each other. The five criteria are briefly explained here, though not in any intended order of priority. 1. Neatness (presentation of the work); 2. Originality (of idea and of material-usage); 3. Ability to achieve the main objective in each exercise (for example, creating motion in Exercise 3 below); 4. Design ability (as defined earlier, this criterion emphasizes the underlying goal of all design, which is to organize parts into a coherent whole); 5. Process (this criterion can take the form of students' written ideas, rough sketches, and "mistakes," better understood if students reoognize these as constructive attempts, discoveries leading to a pleasing finished product). Same form of "process" work is required with each of the student's designs, because I consider the process expressly significant in the total learning experience. Students generally recognize the value in this exercise.

The description of each exercise in group $A$ includes comments by the students and/or some of my own. These are intended to identify strengths and weaknesses in the presentation.

\section{Exercise 1}

This project was designed simply for students to get concrete experience with the definition of design, as given above. Students were to develop four visually related shapes, three of them "geametric" 
and one "organic" in appearance. Several duplicates of each shape were then cut fram black construction paper, and used to create different arrangements of the same four shapes. Directional words such as "horizontal" and "vertical" helped students to control the organizational process. The student, whose work appears in figure 1 , designed shapes, each relating visually to the others and reflecting the directional concepts. On the other hand, several students misinterpreted the purpose of including an "organic" shape, and, consequently, were too concerned about "making the picture look like something" rather than discovering the potential for visual relationships between shapes and how to arrange them within a specified format. The concern to make scmething "worth keeping" is not infrequent among general education students at this level, warranting, perhaps the elimination of the "organic" specification (if only for the sake of making the guidelines less complicated in this first exercise).

\section{Exercise 2}

Each student was required to purchase a deck of playing cards for this exercise. Each student had 52 identical images, making it a practical material, as students could each make several "attempts" with less hesitation and fear. This fear (of possible failure) is usually prevalent among students with little art experience; therefore, sensitive instruction should attempt to alleviate this.

These cards were also used in exercises 3,4 and 5 with the instructor's intent to give students more extensive practice with one 
material, an approach which helps students explore the limits of that material. At first students were skeptical about the seeming lack of potential a deck of cards offered, but in the end everyone was surprised at the variety and ingenuity exhibited in the results.

The assignment in this exercise was to cut up three cards, each one into several straight pieces of even width. In the re-organization of these parts none of the shapes could be left out, only rearranged. The object was to explore how the size and shape of the picture format could be stretched (in three different compositions) while simultaneously arranging the pieces, each one touching another one, in a rhythmic pattern. Each card was to be cut in a different direction, a "rule" which could have been eliminated to give the students a greater challenge in pursuing variety. Figures 2-4 illustrate various perceptions of rhythm, which, with balance, emphasis, and unity, is one of the governing principles in most design. (35) When we discussed the variety of interpretations, we came to agreement that these principles "are so interrelated that it is almost impossible to completely isolate them." (36) It is important that instructors make this clear to students, some of whom otherwise suspect there is only one right answer to the problem. At the same time it is instructive to

(35) Louise Ballinger and Thomas Vroman, Design: Sources and Resources (New York: Reinhold Pub. Corp., 1965), p. 29.

(36) Ibid., p. 26. 


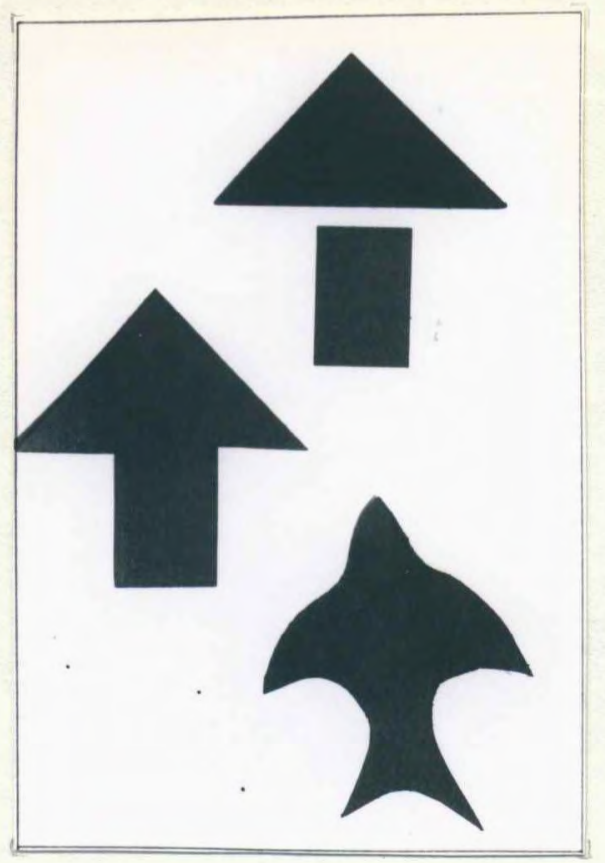

FIGURE 1. Organization studies (Exercise 1).
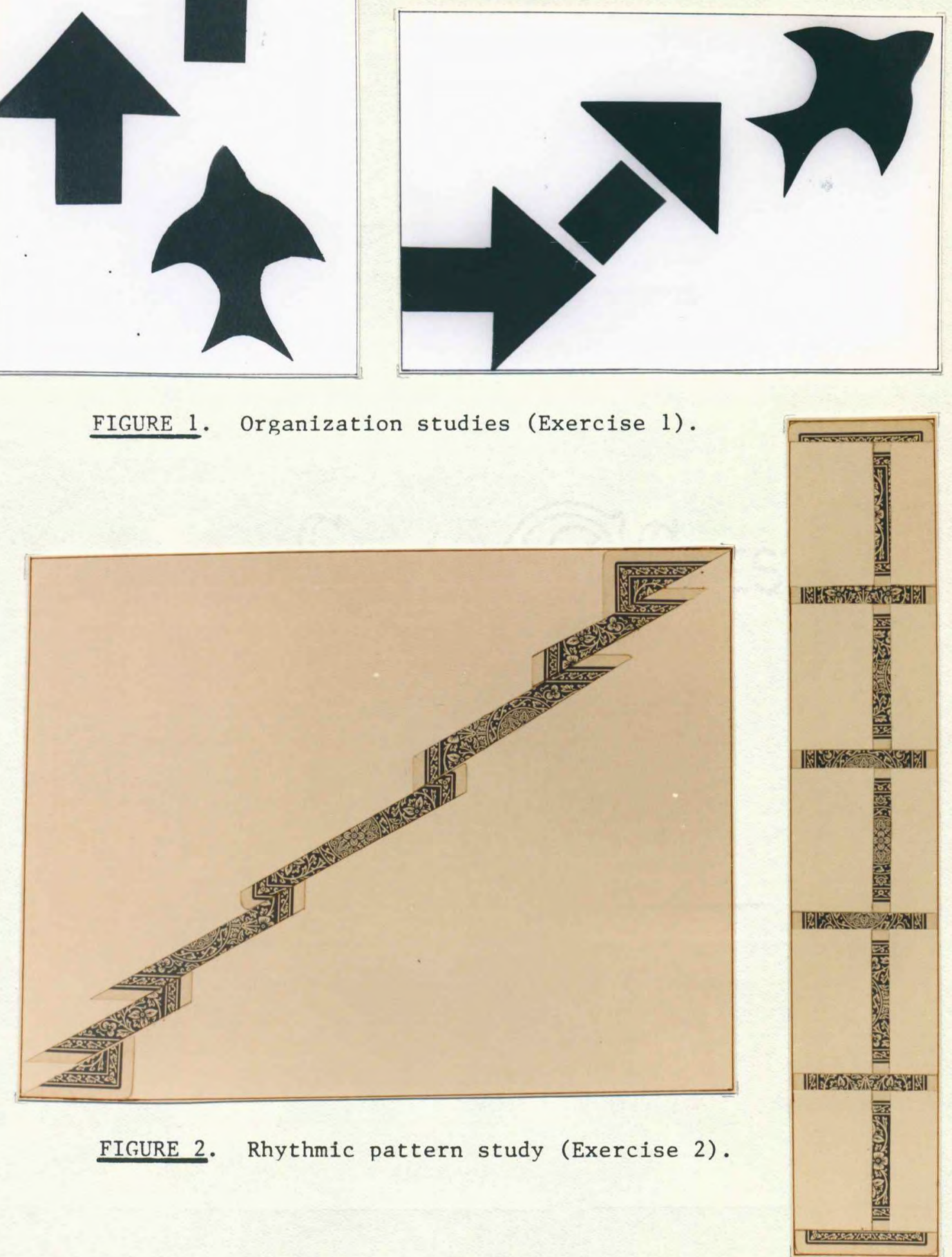

FIGURE 2. Rhythmic pattern study (Exercise 2). 

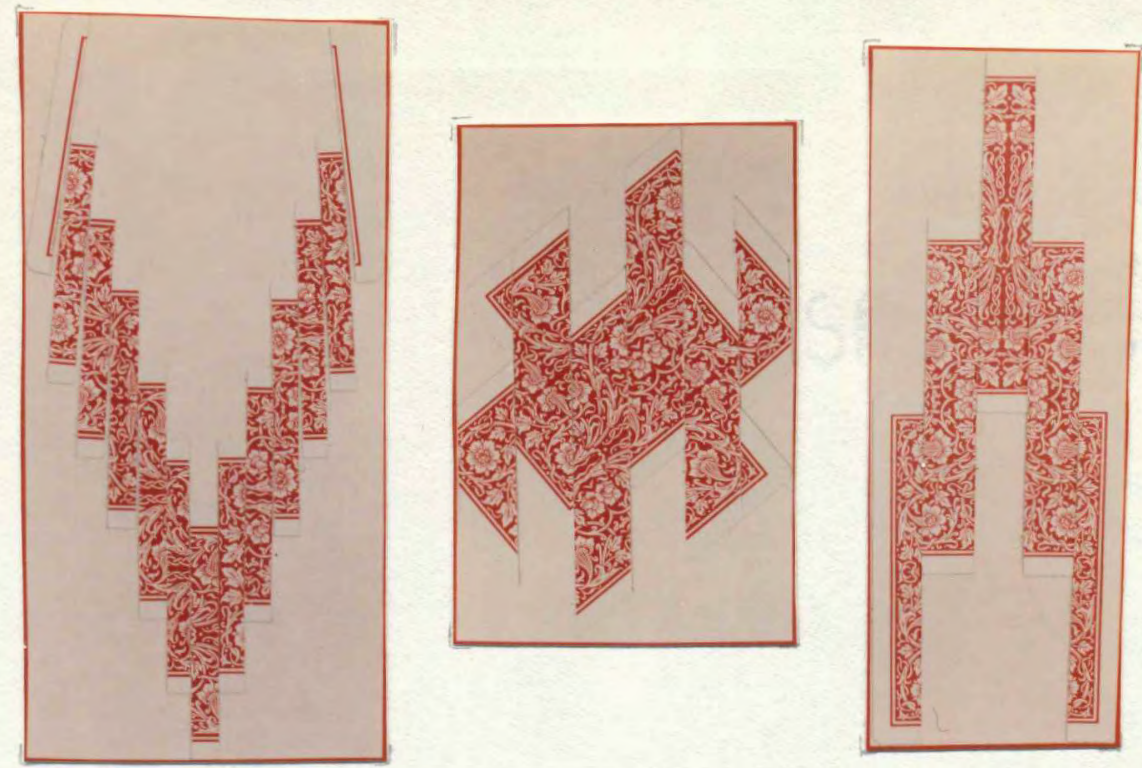

FIGURE 3. Rhythmic pattern study (Exercise 2).
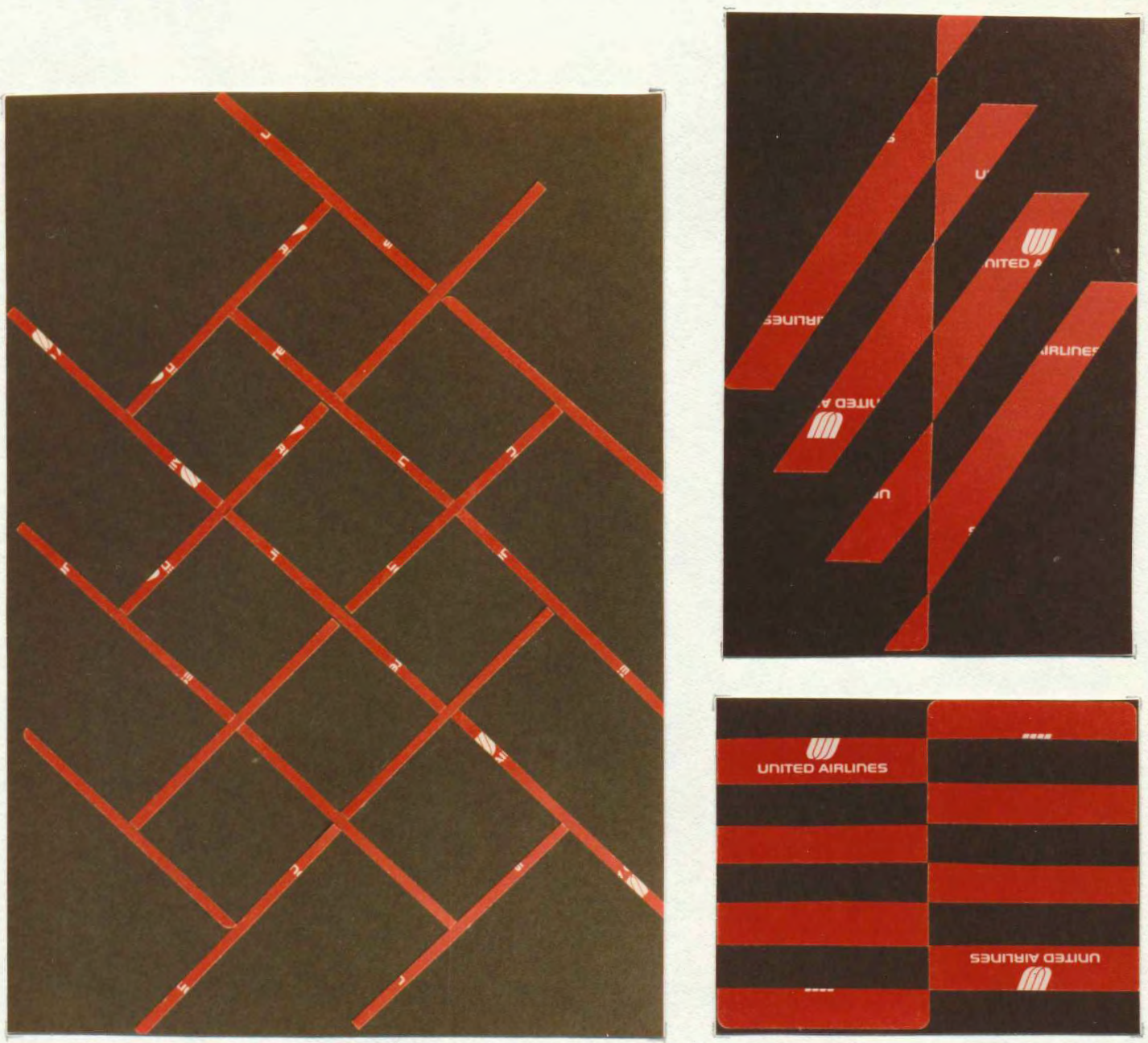

FIGURE 4. Rhythmic pattern study (Exercise 2). 
assign problens which, when solved, attempt to emphasize one principle.

\section{Exercise 3}

The objective of this exercise was to create motion, a quality of rhythm, by cutting up one or two cards and rearranging all the pieces, each part touching another. Students could also cut curved, but even-width pieces in this exercise. The designs in figures 5-7 illustrate very individual interpretations of this problem. One student (figure 5) managed a solution using only one card, and created the illusion of curves even though only straight cuts were used. The other two students were both pleased with their solutions, which exhibit illusions above and beyond the objective of motion. Figure 6, created with two cards, appears momentarily as four, while the two cards used in figure 7 give the appearance of one being "stretched out," acting visually like a coiling spring. By this time, progress in students' visual vocabulary was noted when students explained their works in the "process" report (the fifth evaluation criterion). One student explained that she was "conscious of the negative space." (figure 7)

\section{Exercise 4}

In this exercise students could use any number of cards and they were not required to use up all the pieces in the designs. The cards were to be cut gradually from small to large shapes and arranged to create "graduated rhythm," that is, rhythmic motion which starts and 


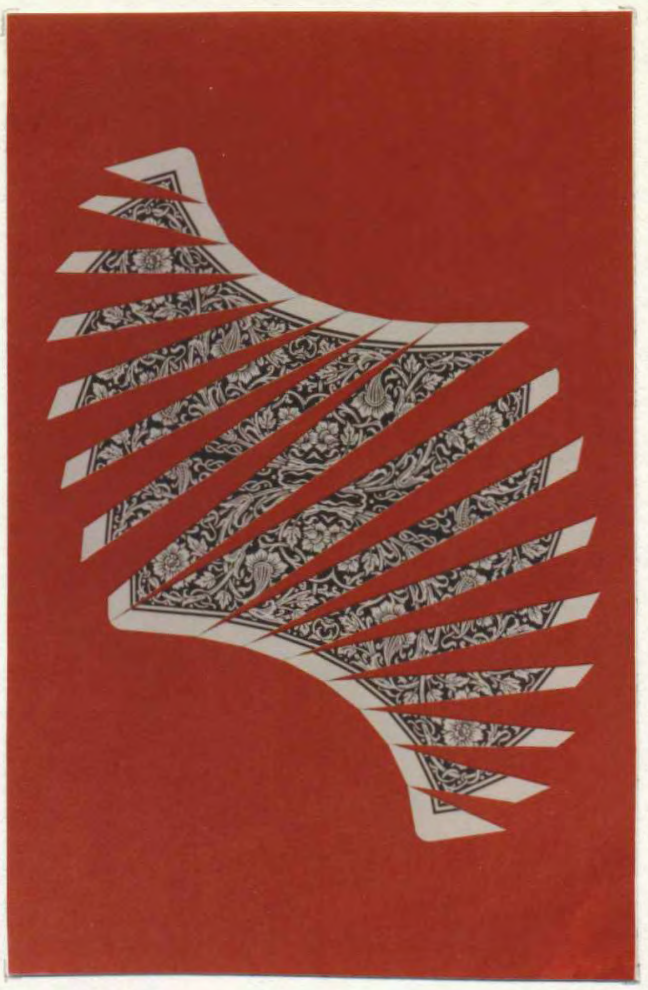

FIGURE 5. Motion study (Exercise 3).
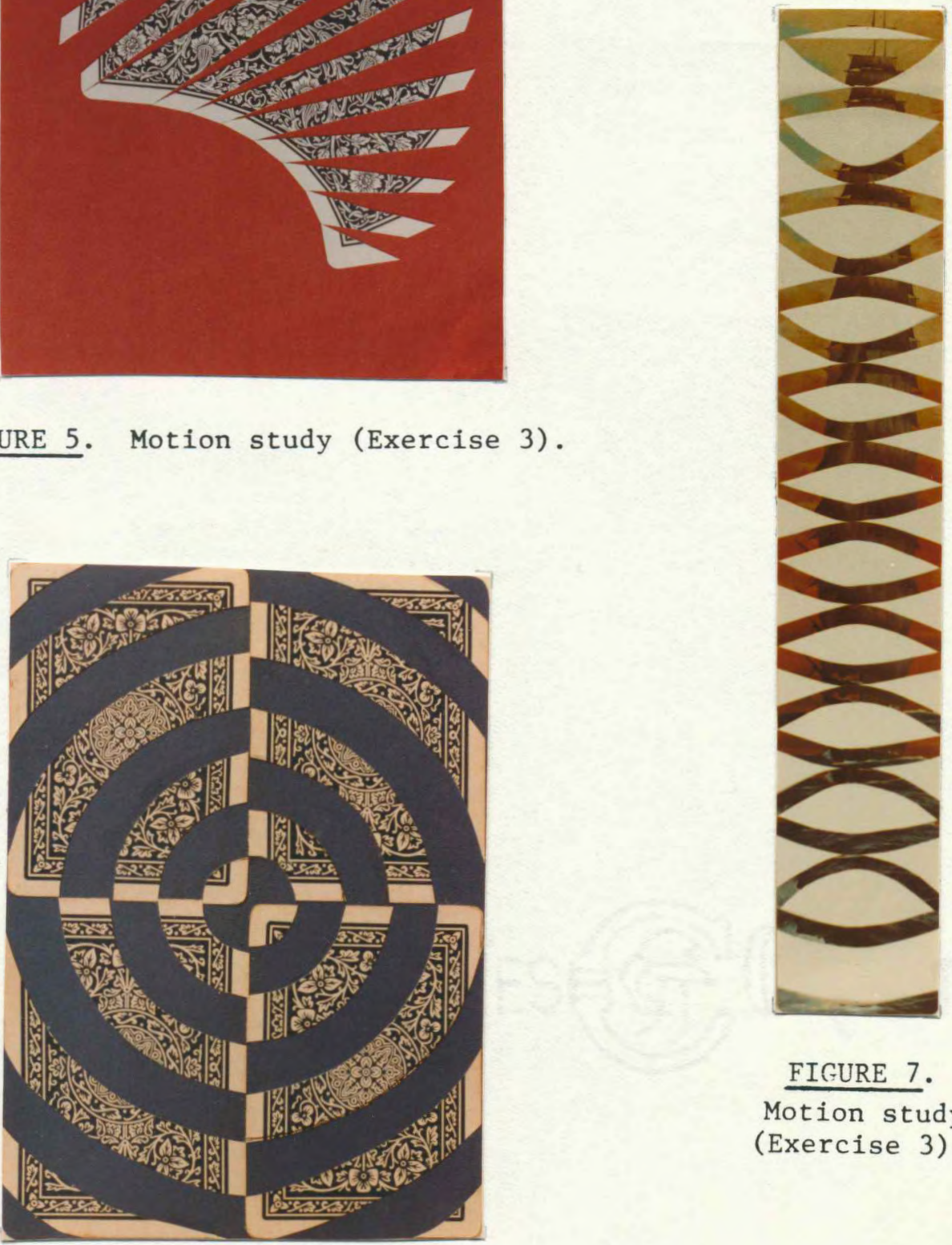

FIGURE 7.

Motion study (Exercise 3).

FIGURE 6. Motion study (Exercise 3 ). 
expands from a specific point. Two designs were required, one using symmetrical balance (figures $8 \mathrm{a}$ and $9 \mathrm{a}$ ) and one using asymmetrical balance (figures $8 b$ and $9 b$ ).

There were too many added variables in this assignment and what appeared to be mixed intentions in the objective. Students, apparently, did not understand that both rhythm and balance can be worked into one and the same design. This indicated a need to be more clear with definitions and, as explained earlier, to teach the principles separately. Interestingly, this approach helps students who are developing a visual vocabulary, and yet, different principles are also noticed and pointed out by students even when those not mentioned in the guidelines appear in the work.

Throughout the entire process I was particularly interested in the development of one student, a science major, whose work is shown in figure $9 a$ and $9 b$. My interest in her case was connected with my desire to see results of my theory. I was hoping that through increased organizational skills, this student would demonstrate a more complete understanding of the artistic process and its relationship to other disciplines, especially her major. These two designs are visually active, and show improvement over work she had done previously. I was aware of her expressed concern that this was her "first art class ever." This shared, coupled with my knowledge that she was a science major, provided an enjoyable teaching challenge. Her statement about figure $9 b$, while written in vague terminology, clearly indicated to me 


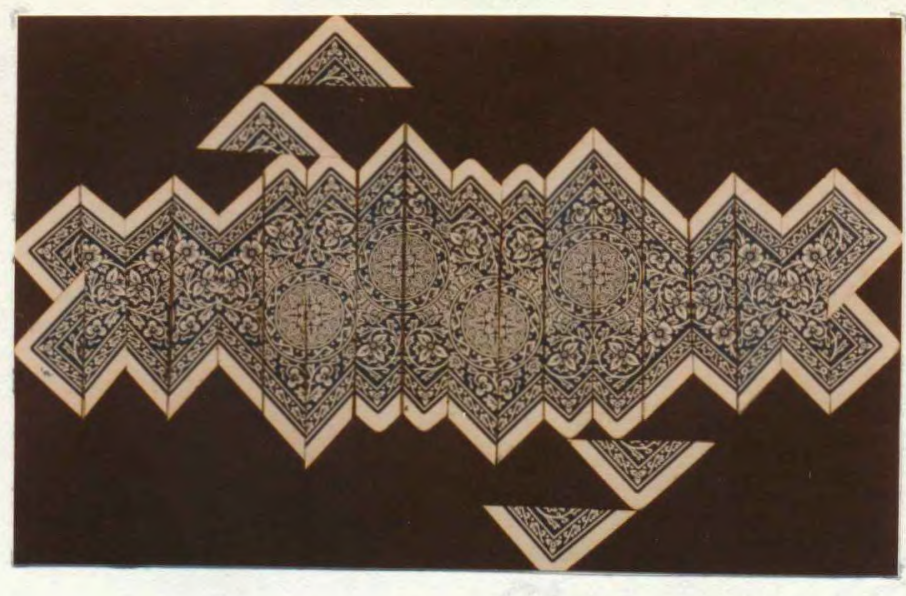

FIGURE 8a. Rhythm studies (Exercise 4).

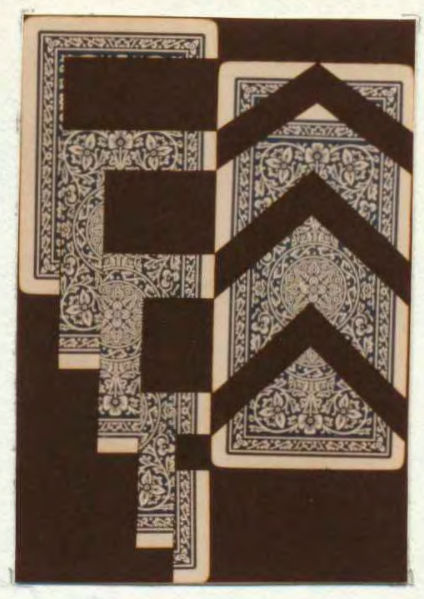

FIGURE $8 \mathrm{~b}$.
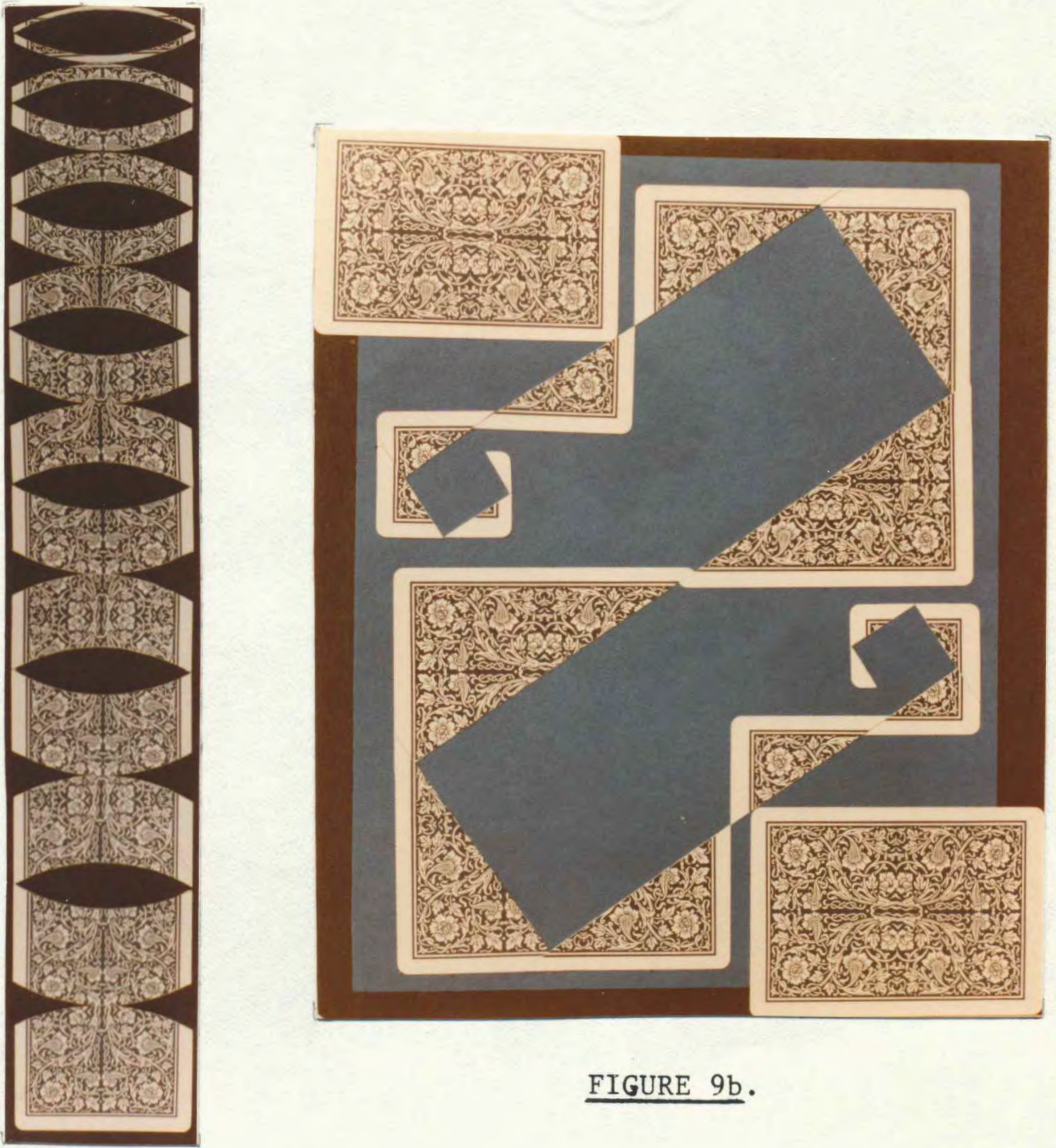

FIGURE 9b.

FIGURE 9a. Rhythm studies (Exercise 4). 
(at the time), her new awareness of part-to-whole relationships, an awareness necessary for both art and science. (37) She reported, "the series of triangular pieces created the illusion of odd card sizes, while the white borders provided a continuum to work with." I concluded fram conversation with her that she understood the importance of what she was saying and seeing.

\section{Exercise 5}

This exercise was the last to make use of playing cards as the design material. In it students explored how to incorporate the face of the card into the design. Consequently, color, texture, and line were more significant elements in this assignment. The pieces of one card were arranged on a specified format; then, students "filled in" the negative space in such a way as to "dissolve" the card's image into the background. Figures 10 and 11 show clever and distinctly different solutions to this problem. Figure 10 shows a literal, but effective, interpretation, in which the color and textures were carefully adapted.

Figure 11, on the other hand, demonstrates a perceptive synthesis of this objective with those learned in same previous exercises. The principles of rhythm and repetition are effectively employed in both positive and negative areas for an attractive solution.

(37) Jacob Bronowski, "The Discovery of Form," Structure in Art and in Science, edited by Gyorgy Kepes (New York: George Braziller, Inc., 1965), p. 56. 
One student, having tired of the cards, wanted to abandon this exercise and continue working on ideas she had developed in exercise 4, but this time using magazine photos. Her achievement demonstrated the importance of flexibility in instruction (figure 12). It is a perceptive creation using the principle of rhythm by graduated size and showing motion in opposite directions at the same time. The psychic and spatial illusions were increased when she included the faces, and I consider it one of the finest student works that I have seen in $m y$ teaching experience. The student's visual perception is equally matched by her ability to describe her illusion; it is "the process of looking outside from within." This is an insightful thought when one considers that the student intentionally selected the boy's face to represent the Eastern hemisphere, while the waman's face represents the Western hemisphere of earth. This is a perception one does not expect, let alone see in its fruition, when assigning a simple design problem. This student, incidentally, is also a secondary science major, one of those rare individuals who has learned how to balance the brain's hemispheres, as, for example, Leonardo did.

The last three exercises in group A need some introduction.

Letter forms are an appropriate medium for integrating art and language, evidenced in the rich calligraphic heritage passed down to us from the Carolingian schools of Charlemagne. This was the primary reason letter forms were chosen as the visual substance with which to do exercises 6, 7 and 8, even though the integrative aspects were not 


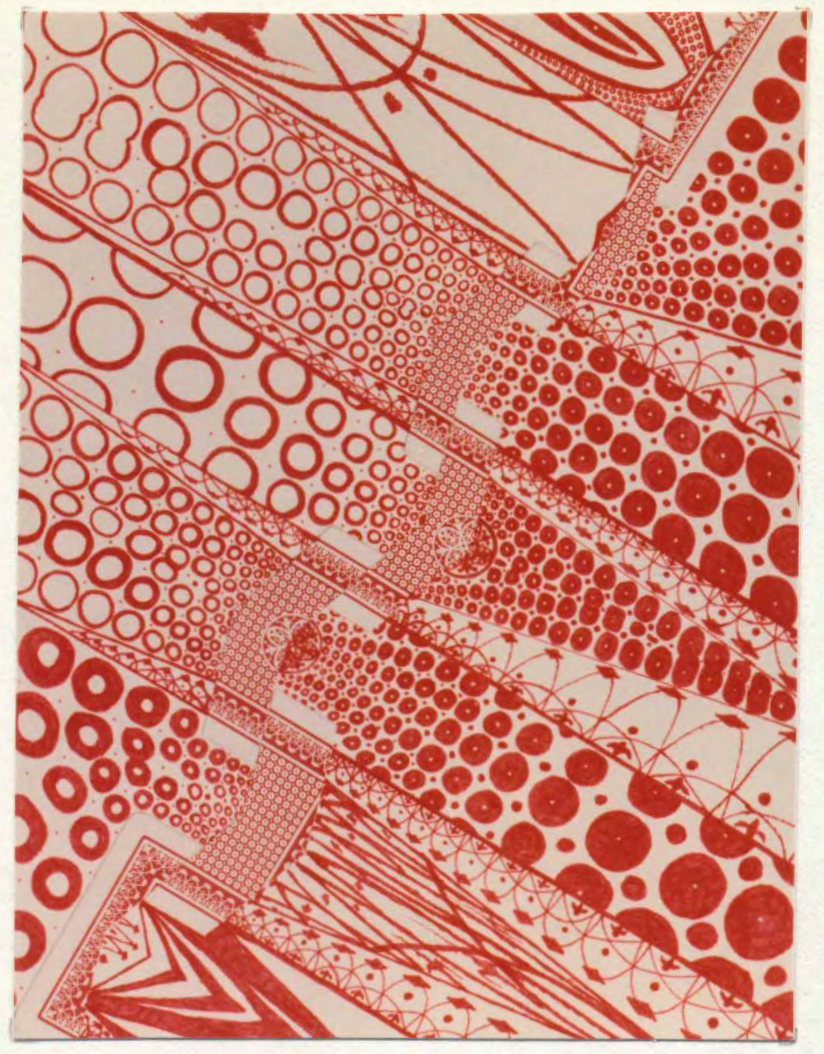

FIGURE 10. Texture study (Exercise 5)

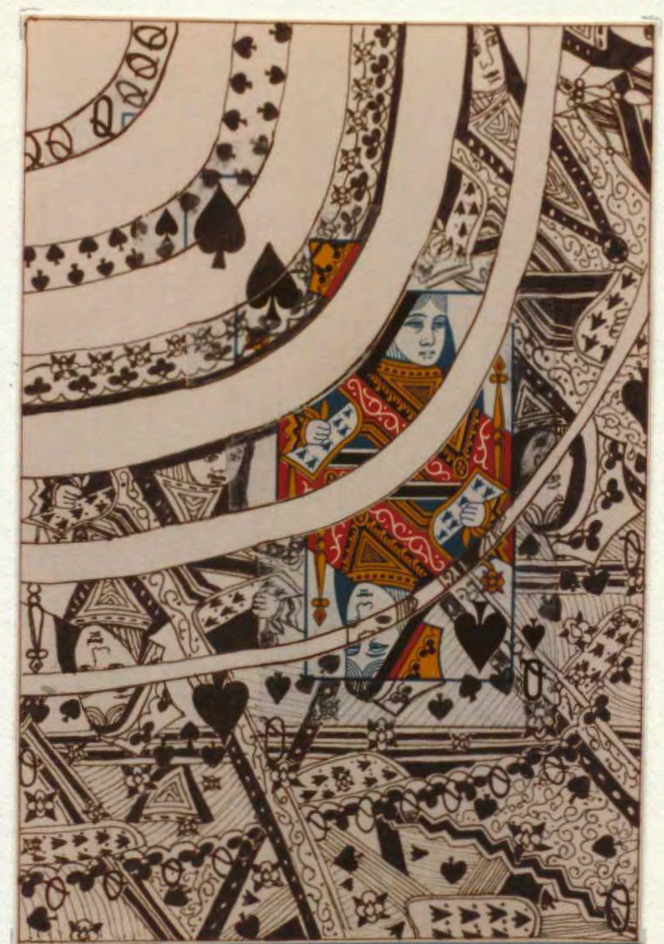

FIGURE 11. Texture study

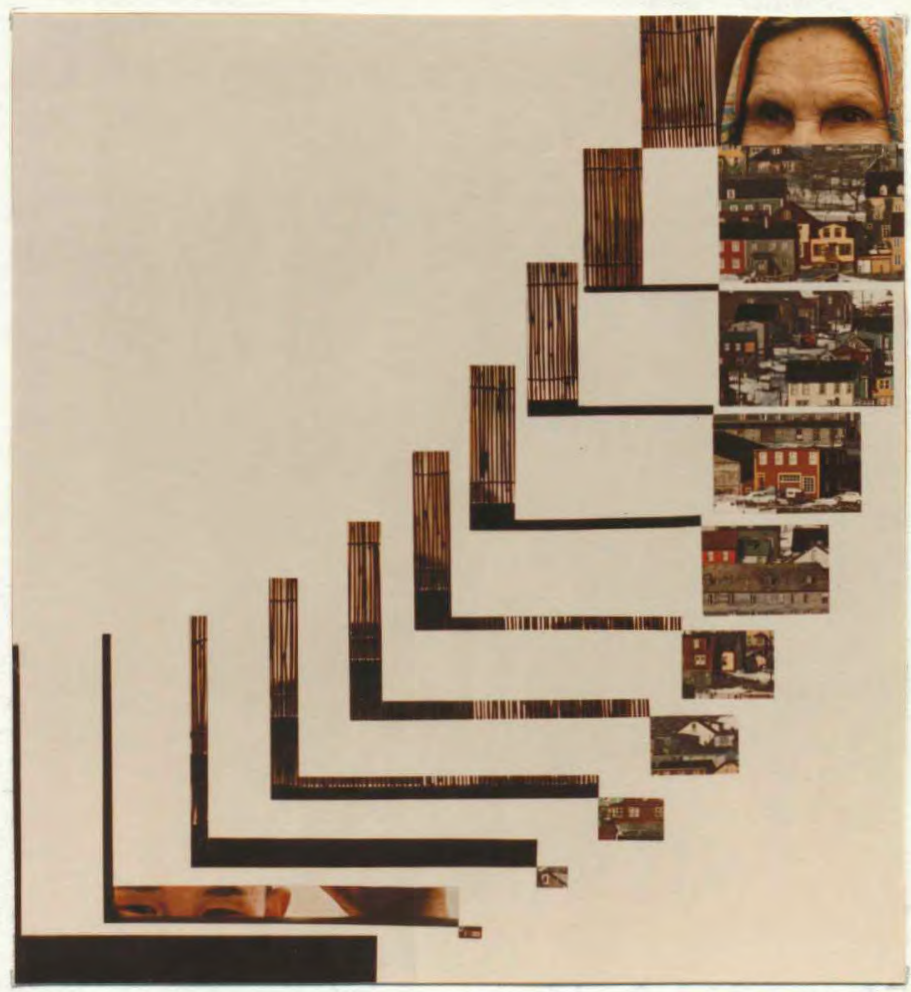

FIGURE 12. Student's personal study. 
emphasized until later. Again, a variety of approaches with the same medium was useful for more in-depth understanding of the design process.

At first, however, I experienced difficulty in expressing to students how letter forms can be used purely as visual shapes, that is, with no reference given to their verbal meanings. Perhaps it would have helped to read the following quote by Wassily Kandinsky: "When a reader looks at some letter in these lines with unskilled eyes, he will see it not as a familiar symbol for a part of a word, but first as a thing." (38) Kandinsky was referring to the lines and shapes of letters which can denote happiness, sadness, defiance, depending on the letter and the person perceiving it. (39) It was this visual quality in letters which was of primary concern in exercises 6,7 and 8. Later, in group $B$, references to art and language relationships acted as a motive in more verbally-oriented images.

\section{Exercise 6}

In this exercise individual letters were clipped from newspapers and magazines to create an asymetrical design. The design principle of "emphasis" was to be used in one of three ways: a change in letter shape, a change in letter size, or a change in the light/dark build up

(38) Wassily Kandinsky, "On the Problem of Form," The Blaue Reiter Almanac, (New York: Viking Press, 1917), p. 165.

(39) Ibid., p. 165. 
of letter forms. (40) Figures 13 and 14 illustrate the latter two respectively. The students' verbal responses signified some new awarenesses. One student wrote, "I became much more aware of the letter styles and the feeling they put across visually. I liked looking at letters in a purely visual manner, disregarding what they communicated verbally." The student whose design is shown in figure 14 wrote, "I was experimenting. Now I see it would be fun to make a picture - perhaps a mountain with a moon at night - using letters like this." I was pleased to know that the student realized a personal purpose for developing her visual skills.

\section{Exercise 7}

Students used large letter fragments, clipped from magazines and newspapers and hand-made where needed to achieve this assignment. The intent was to develop the illusion of several transparent and overlapping shapes, dividing and fracturing the total area into several smaller ones. (41) The results show various degrees of fragmentation and transparency (figures 15-18). At first it was difficult to

(40) This idea was adapted from content in Wucius Wong's Principles of Two-Dimensional Design (New York: Van Nostrand Reinhold Company, 1972), Pp. 67 and 71.

(41) This idea was adapted from content in Maurice de Sausmarez, Basic design: the dymamics of visual form (New York: Reinhold Publishing Corporation, 1964), p. 42. 

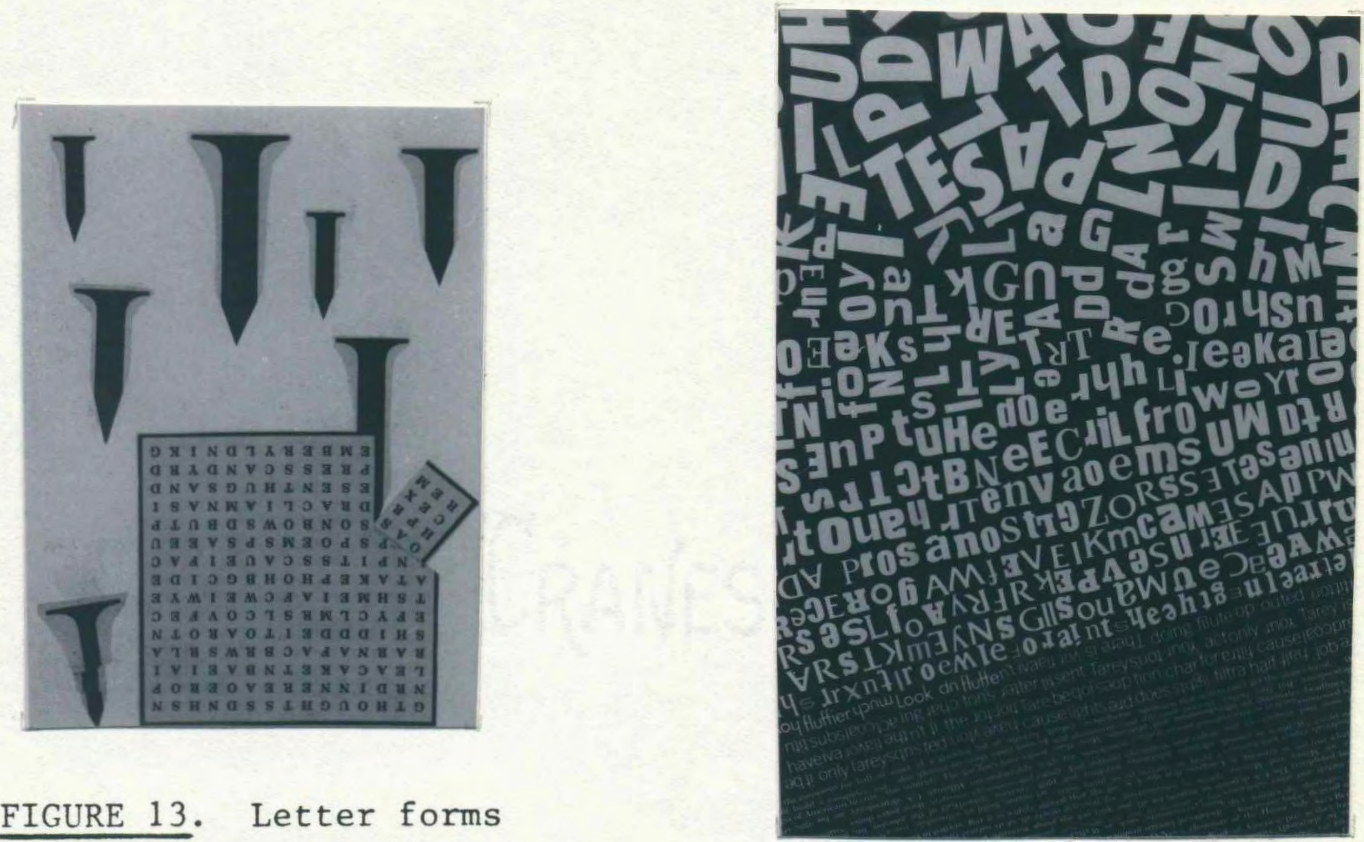

FIGURE 13. Letter forms study (Exercise 6).

FIGURE 14. Letter forms study (Exercise 6). 
communicate to students how they might proceed with this project. Two things seem to have aided in the students' understanding. First, I encouraged the use of fragments, letters which appear to be less than whole. Then, I encouraged students to think of the negative spaces as an active element, chopping up letters. Once this was understood the illusion of transparency fell into place. One student wrote about her design (figure 17), "all of the space is used," acknowledging her understanding that negative space can be actively positive. Another student wrote how he "became delighted with the organized confusion," identifying the understructure (of two-inch squares) as the controlling element in an otherwise "chaotic," yet "very vibrant work" (figure 16). In my own perception, figure 18 is a superior illustration of the intended objective. Some students admitted they never understood the assignment, perhaps because no specific design principle was written in the objective, as in exercise 6. Nevertheless, the majority of students made important progress during this exercise.

\section{Exercise 8}

The last of the exercises in group $A$ was designed to be transitional, meaning that components of it relate specifically to content in group B, exercise 2. This exercise has been added to the sequence as a result of same needed changes I perceived after the projects had been presented. The visual examples, figures 19 and 20 were actually done by students as an "optional" interpretation of exercise 6. Here, however, the effect of emphasis was to be achieved 


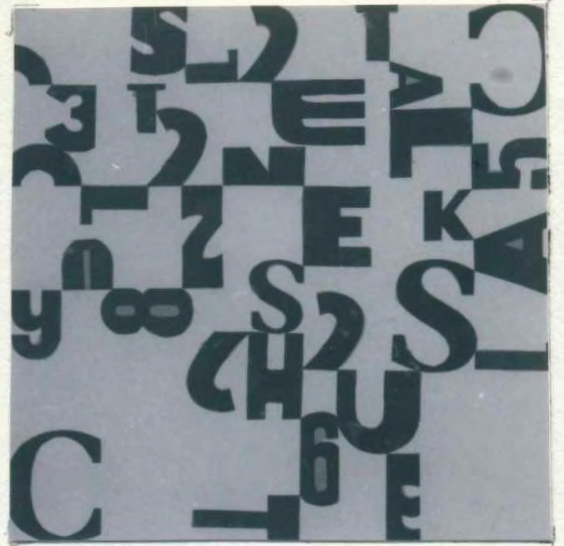

FIGURE 15. Fragmented letter forms.

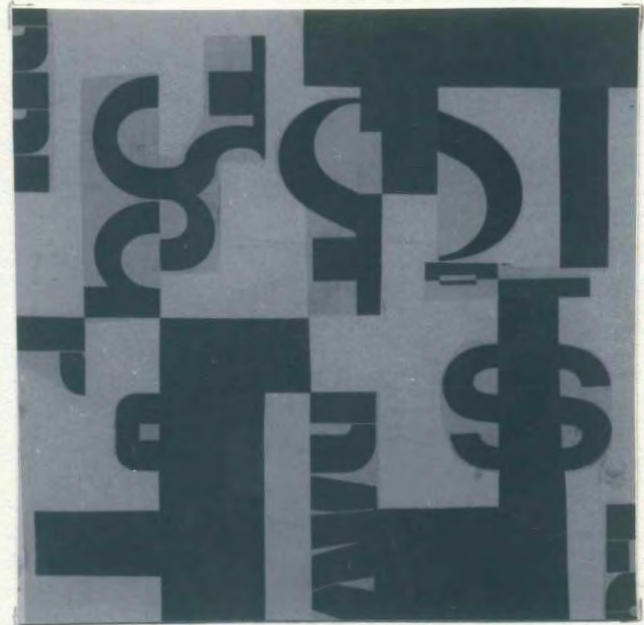

FIGURE 17. Fragmented letter forms.

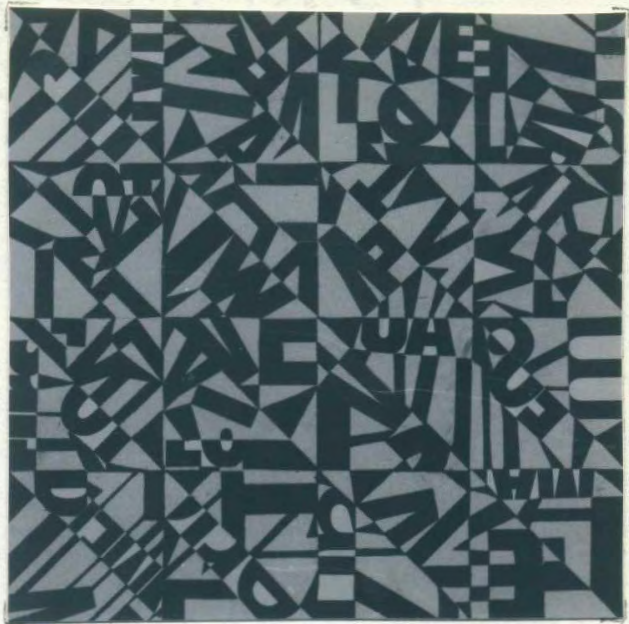

FIGURE 16. Fragmented letter forms.

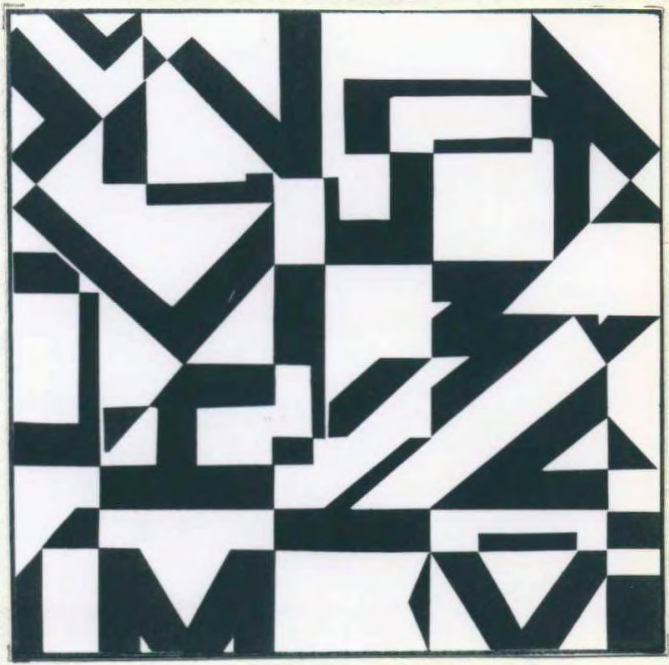

FIGURE 18. Fragmented letter forms.

(Exercise 7) 


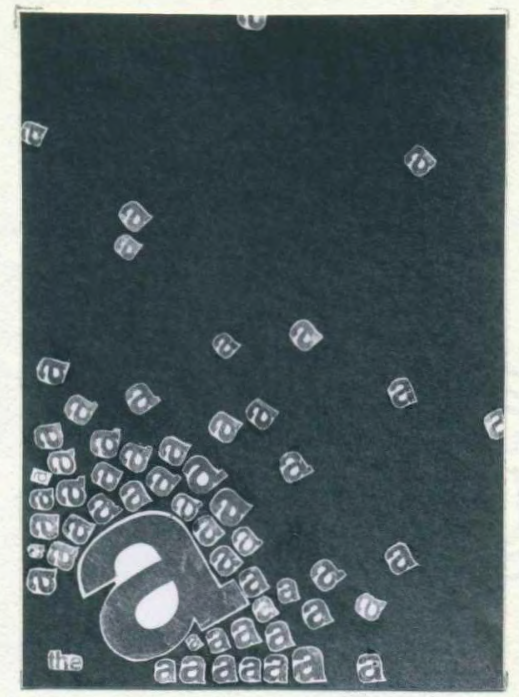

FIGURE 19. Visual/verbal study (Exercise 8 ).

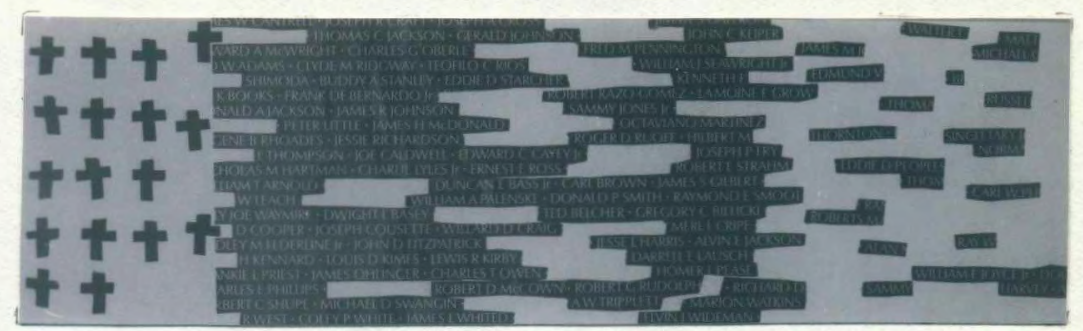

FIGURE 20. Visual/verbal study (Exercise 8). 
in two ways; 1) in the arrangement of letter forms; and 2) in the placement of a word or words, the verbal meaning of which should reflect the meaning of the design. Only a few students even attempted the option, which was probably best; I realized later that its content was too complex when they had not yet practiced with letters as visual forms. Its placement in the sequence is appropriate here, after students have practiced with the visual quality in letters and before art and language relationships are presented as design motives.

Figure 19 shows an attempt to illustrate the meaning of the word "the," the only specific in a field of unspecific articles. It is a perceptive arrangement suggesting, in a metaphoric way, the uniqueness of individuals in society who receive acclaim as the best, the richest, etc. Figure 20 speaks for itself as soon as one recognizes that the rows of letters are actually the names of those who were "missing in action" during the viet Nam war. After submitting the design the student realized that her message would have been more coherent had she put the crosses (symbolizing a graveyard) at the right instead of the left. In this way, the visual movement toward the crosses would coincide with the "direction" in which we read English. This awareness, even though it came after the fact, was an important acknowledgement of the link between visual and verbal organization. 


\section{LINKING ART AND OTHER SUBJCCIS (GROUP B EXERCISES)}

The exercises presented in this chapter emphasize the "motives" approach to art education. I decided to teach these exercises, after, rather than before, students had developed some basic visual skills, because the content accompanying these exercises is more complex.

In these exercises apparent relationships between art and other subjects were used as the content for visual problems as well as a means to understand, more fully, how creativity in art can aid the same in other subjects. While some of these relationships have already been discussed, each exercise in group B will begin with a description of the specific context used in presenting it. Again, this context was intended primarily as "motive" for creative interpretation during the design process.

Exercise 9 - Art and Science

A single sentence expresses what was the context for the activities explored in this exercise: The methods of doing art and science are interrelated. (42) The activities corresponding to this interrelationship received the most extensive attention ( $31 / 2$ weeks) during the course. This was partly due to the format of the exercises (presented below), but especially to my interest in ideas currently

(42) Cassidy, pp. 17 and 21. 
being considered for a course in art and science. My colleague, Johnnie Driessner, is a biologist and my cohort in this endeavor. We are examining ways to augment the learning of art and science by teaching them together. This, however, is beyond the soope of this thesis. Instead, $\mathrm{my}$ primary goal was to illustrate some conceptual relationships between art and science in order to make students more aware of how the process of art, no less than science, is an intellectual one.

First of all, some information regarding the cognitive processes common to and distinguishing art and science was presented to students as background for the exercise. Students understood that this information would be used as only one possible approach for doing and understanding the discovery process. The interrelationship of art and science is described by Harold Cassidy in his book, The Sciences and the Arts: A New Alliance. "The processes of art and science," he says, "include three related and overlapping kinds of functions: 'analytic,' 'synthetic,' and 'reduction-to-practice.'" (43) He continues by saying that in the arts and sciences the "analytic" activity "involves accumulating data... making collections, naming, observing, and reporting observations in detail." The synthetic activity "occurs when connections are sought among data, among theories, and among theories of theories." This takes place in both art and science. Finally, "reduction-to-practice" is "the activity which returns from the general or theoretical to the particular or practical... Ultimately... it is in their application, their reduction to practice, that the results of 
analytic and synthetic activities are tested for validity." (44) The visual activities which reflected this information were organized according to the first two of these functions. "Reduction-to-practice" was not included due to a lack of time and because general education students need not be pressured into producing testable visual theories. The activities were introduced with two illustrations, one from art and one from science, each of which showed how the "analytic" function leads into the "synthetic" function. The art illustration included a presentation of color slides explaining what Helen Gardner called the Analytic and Synthetic stages of cubism. (45) For Picasso and Braques, its inventors, this involved a lengthy kind of step-by-step process. That Picasso waited about 15 years before writing his thoughts about cubism, (46) is an indication of how involved the process of art can be. And, although our process would not be as involved, the illustrations gave students an understanding that they would be going through a similar step-by-step process.

The science illustration related how Leonardo Fibonacci, a 13th century mathematician, developed his theorem now referred to as the

(44) Ibid., p. 23.

(45) Helen Gardner, Art Through the Ages, 6th ed. (New York: Harcourt Brace Jovanovich, Inc., 1975), pp. 730-732.

(46) Excerpts of this first statement by Picasso are in Herschel B. Chipp, Theories of Modern Art (Berkeley: Univ. of Calif. Press, 1968), p. $263 f$. 
Fibonacci series. (47) It has been demonstrated that various ratios existing in this series of numbers can be found all over in nature, including the human body. (48) By referring to Cassidy's model, one can see that these careful observations, which were accumulated, correlate to the "analytic" function. The accumulation made it possible to formulate the mathematical theorem, an activity correlated with the "synthetic" function. All of this is explained, as briefly as possible to indicate what was presented to students as background for the art process. Students appreciated seeing the relationship between art and science even though it was not yet clear to them how it would affect their own process. They were informed, however, that the exercise would consist of, first "analytic," then "synthetic," activities.

The "analytic" parts of this process were presented in the form of several drawing activities which are briefly described below. I referred to each of these activities, when it was introduced, as a part of the "analytic" stage of the design process. As such, students were told that these were not to be creative endeavors so much as a collection of "visual information" to be saved and later used in the "synthetic" activities. Students agreed (when the whole process was over) that it was good not to know ahead of time how the "analytic" activities would affect the "synthetic" stage; it was enough to know they would be using the "visual information" later in the process.

(47) Esther Warner Dendel, Designing Fram Nature New York: Taplinger Pub. Co., 1978), pp. 38-46.

(48) loc. cit., pp. 38-40. 
Each student collected "visual information" by drawing from a personally selected fruit or vegetable. The activities helped students to see various kinds of detail in each form, which led them to realize the potential for designing from nature.

For the first "analytic" activity I chose a drawing method which would relax the less experienced while keeping their interest in the subject matter. This method, introduced in 1941 by Kimon Nicolaides, is referred to by Betty Edwards as "pure contour drawing." (49) The object is to draw every detail observed without looking at the drawing paper. Students generally responded well to this technique once they realized proportions did not have to be exact. Each student did two pages $\left(18^{n} \times 24^{n}\right)$ of these studies and then saved them for future use. The second "analytic" activity involved more extensive observation of the fruit and vegetable forms (figures 21-23). Students each did 12 drawings, somewhat "abstracted" from what they observed under magnifying glasses and microscopes. They understood that drawing while using science tools did not necessarily define the activity as either art or science. Four stations were set up where students observed and drew the forms, under different magnification levels, at each station. A microtome was available at one station for students to make small specimen slides for observing the cell structures of their objects. I encouraged students to write the magnification levels on each drawing, reminding them that any information noted in the "analytic" process might later be pertinent in the "synthetic" activities.

(49) Edwards, p. 82. 
Same students had difficulty understanding the meaning of the word "abstract," but this seemed to be resolved as we proceeded. Most of them were pleased when they realized the drawings were not expected to appear "realistic," with every detail showing. Rather, students learned to record a variety of shape and line patterns observed in their three-dimensional plant-forms.

The third and final "analytic" activity (illustrated in figure 24) gave students practice in light to dark progression. Students were required to do at least three different progressions using massed lines to build up the various levels of gray. Interestingly, the student whose work is illustrated here, acknowledged the scientific approach she used to create the progressions. One student "stretched the rules," to his advantage, by basing his light/dark progressions on shapes observed under microscope, instead of the massed lines. He was able to use this technique in his finished design (figures 27a and 27b) .

To begin the "synthetic" activities I introduced the design problem. Students were to create an abstract "landforms" interpretation of their fruit or vegetable. The required dimensions of each design was a golden rectangle, $8^{n} \times 13^{n}$, the proportions of which fit in the Fibonacci series. (50) The object was to select (from all the "visual information") whatever was appropriate for a personally satisfying and coherent design. Students understood this to be the "synthetic" activity, our particular (oognitive) way of describing the design process. To govern this process they were instructed to use the

(50) Dendel, p. 41. 


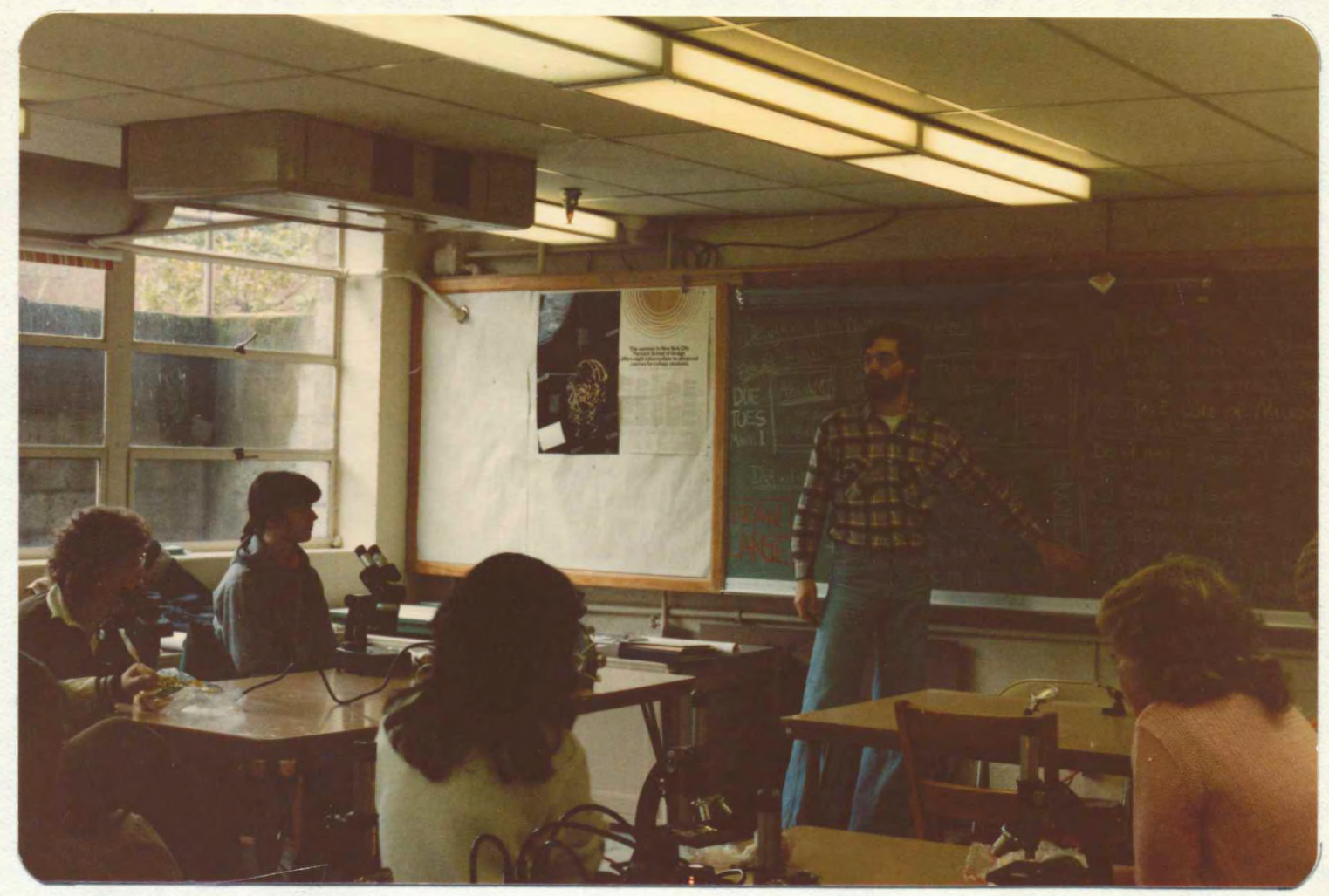

FIGURE 21. Concordia art room (Exercise 9).

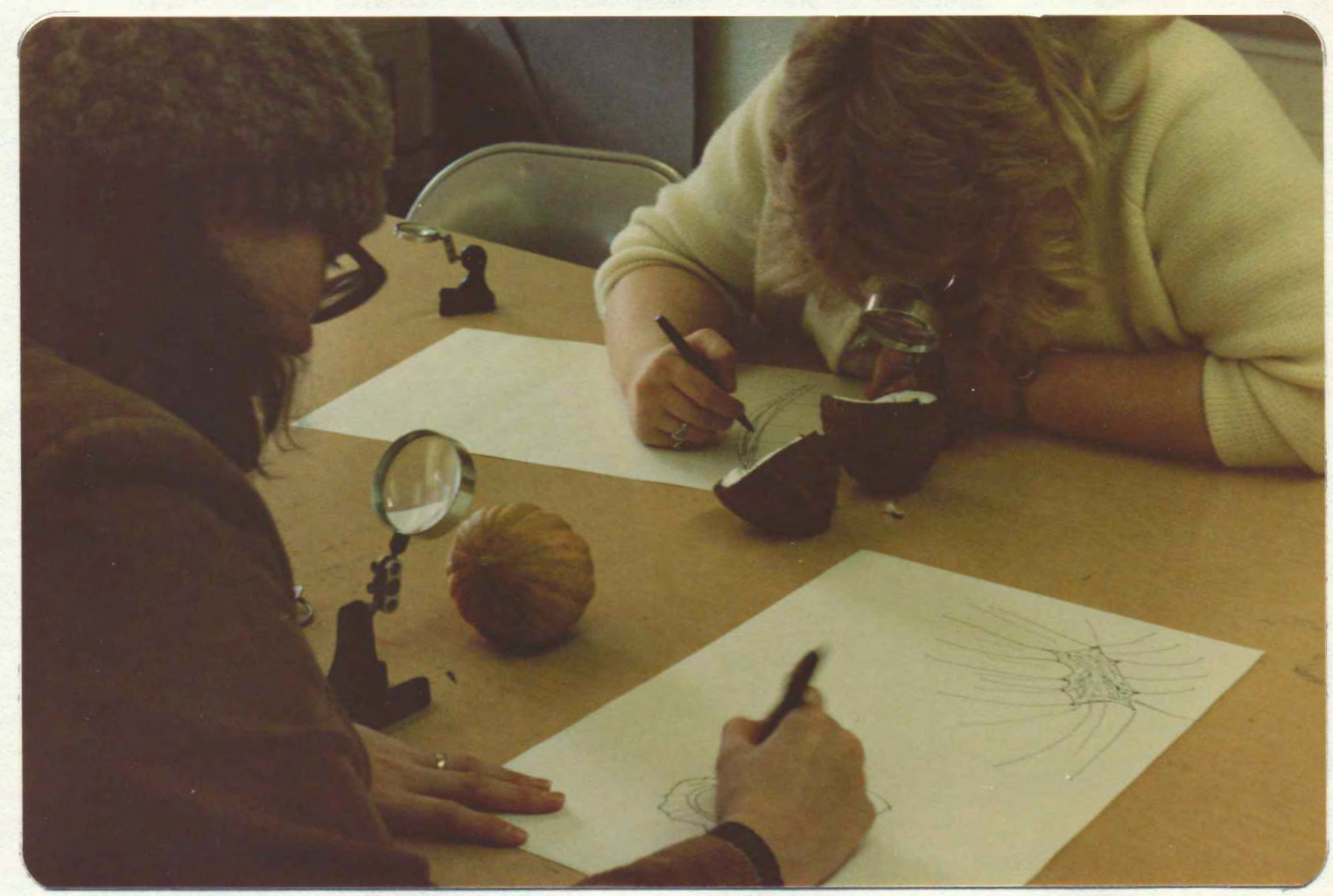

FIGURE 22. "Analytic" process (Exercise 9). 


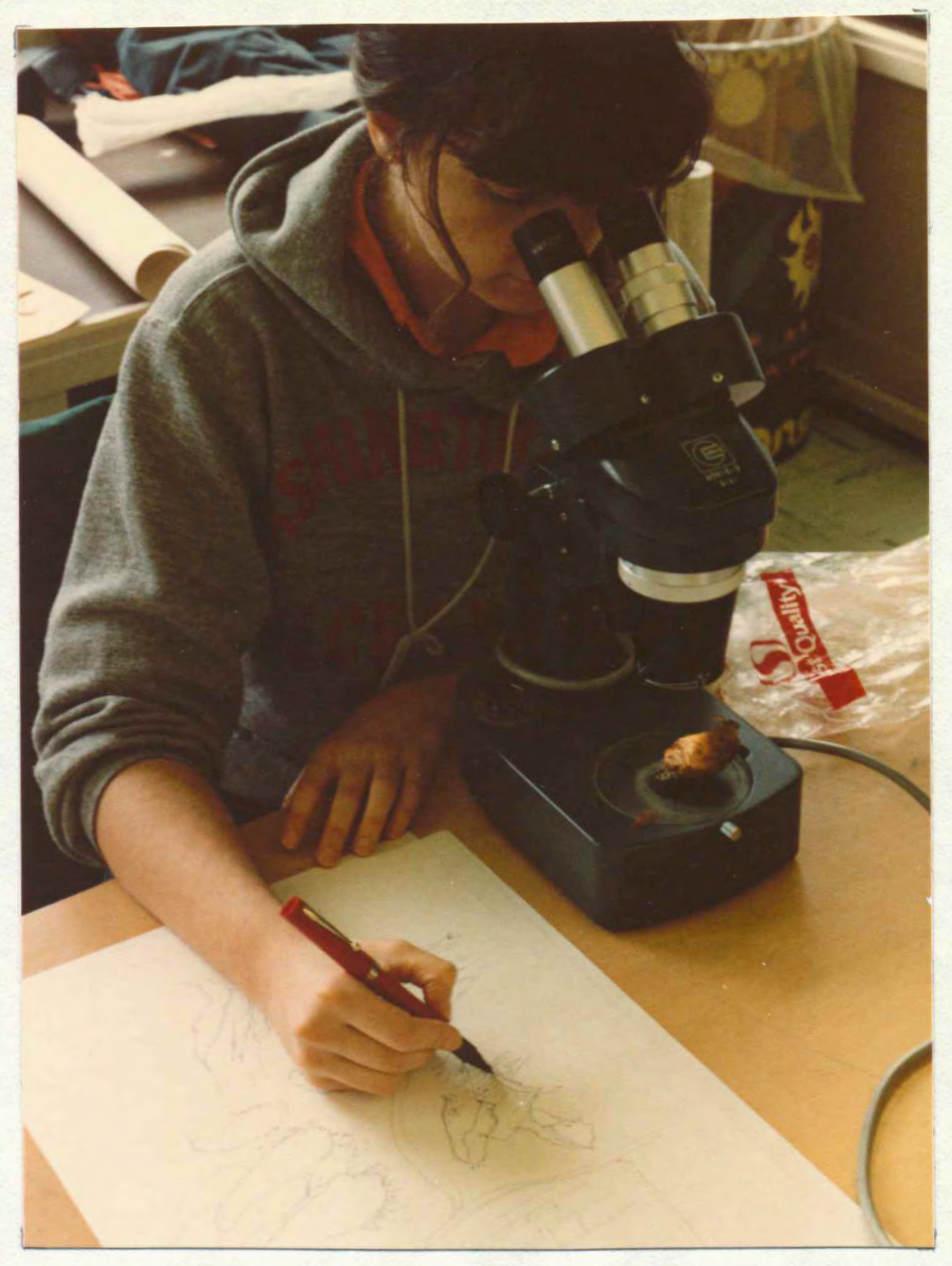

FIGURE 23. "Analytic" process (Exercise 9).

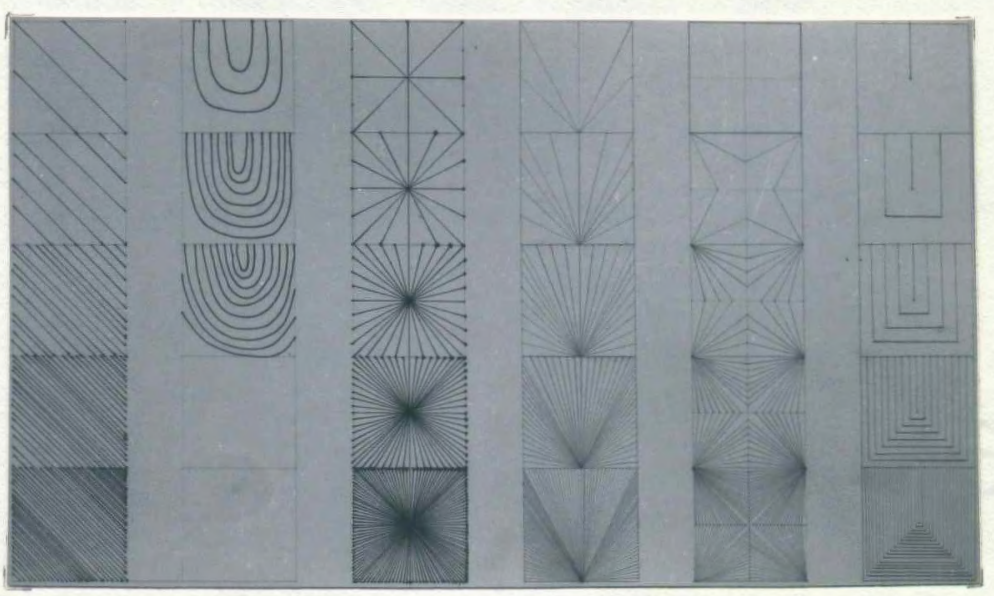

FIGURE 24. Value progression - "Analytic" process (Exercise 9). 
principle of "emphasis," a principle learned during group A exercises. I divided the "synthetic" process into two activities. In the first activity each student did three pencil studies (each in the dimensions of a golden rectangle). A brief demonstration showed how students could use tracing paper to combine parts, from more than one drawing, into a design. At this point students were encouraged to seek relationships, an idea cormon to both art and science. With the instructor's guidance the students then chose one study to be translated into pen and ink for the finished product. (51) Figures 25-27 illustrate how some of the ideas evolved from the microscope drawings into the final synthesis.

Even though several students mentioned their frustration that there was too much "visual information" to synthesize, they also expressed appreciation in knowing more about this approach to discovery. The figures exhibit a variety of successful interpretations, each one indicating the student's awareness of fruits and vegetables as potentially rich sources of design. Figures 28-31 illustrate other examples of this art and science project in their completed form.

Student comments about this exercise reveal their cognitive develogment. As before, these comments appeared in each student's explanation of the process. One student remarked, "I gradually understood the concept of abstraction, by studying only the design of the object, [and] concentrating on lines, patterns and textures."

(51) The procedures for this assignment were adapted from ideas in Esther Dendel, Designing From Nature, pp. 47-51, 72-87. 

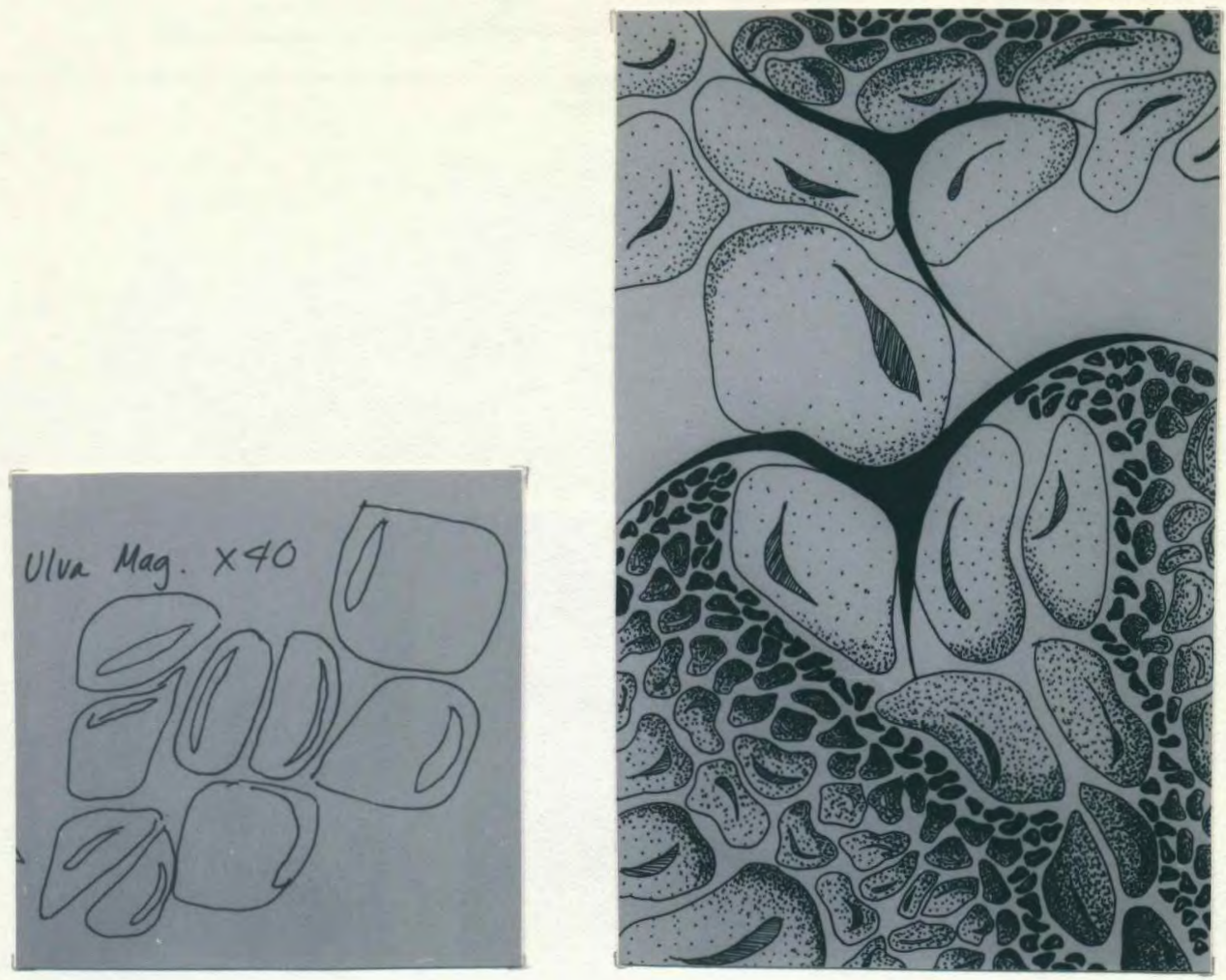

FIGURE 25. Analysis to synthesis by M. (Exercise 9).
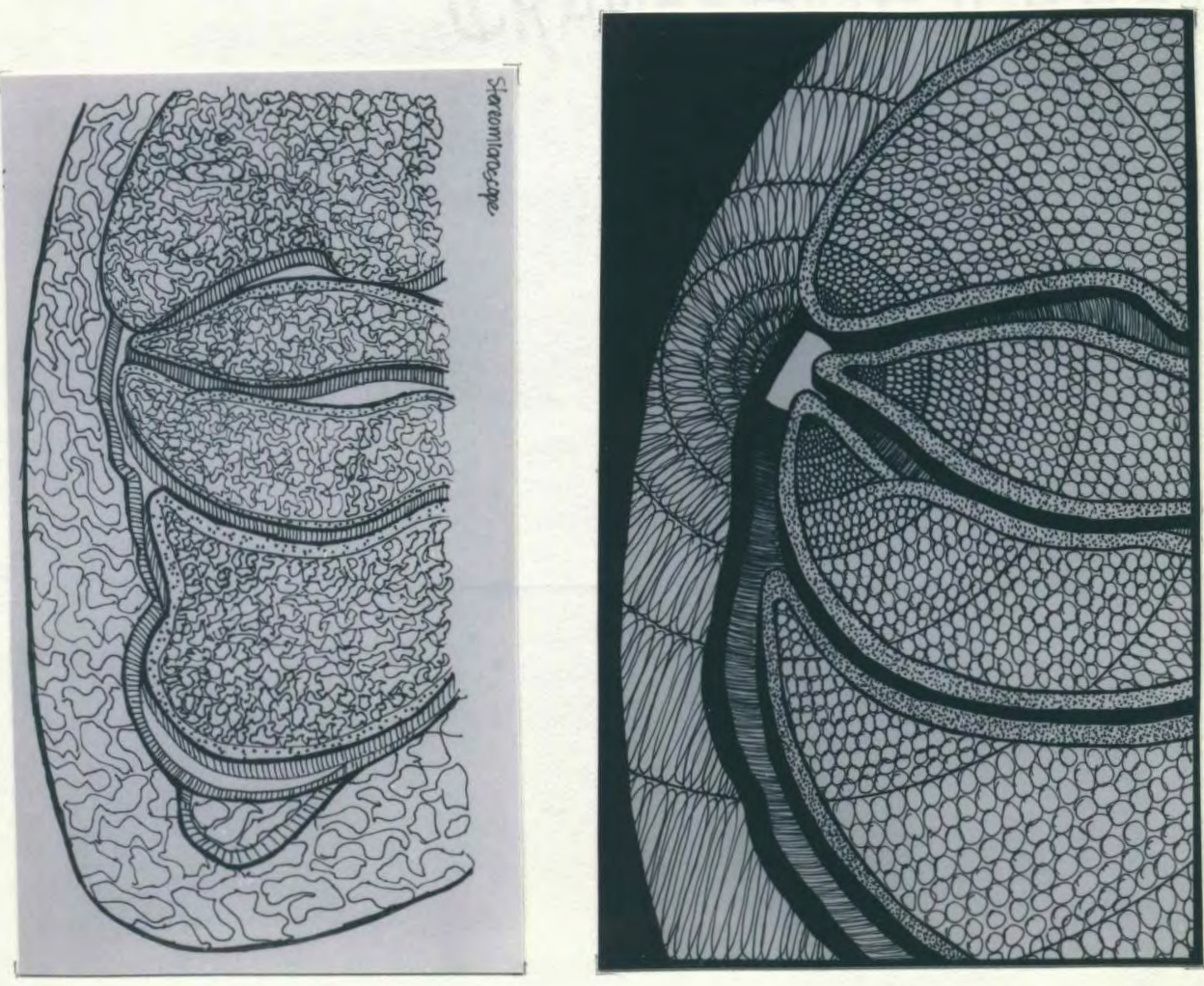

FIGURE 26. Analysis to synthesis by C. (Exercise 9). 

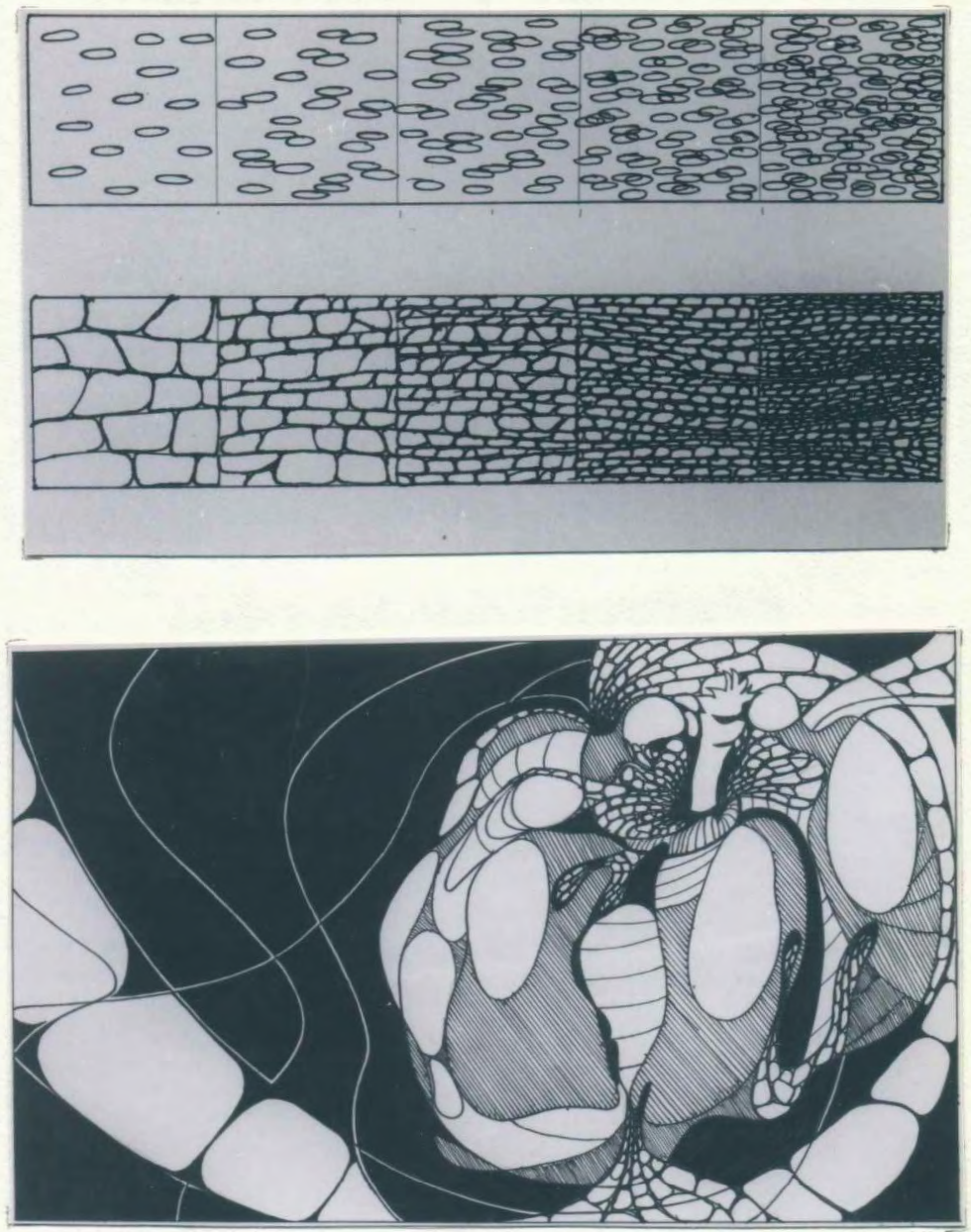

FIGURE 27. Analysis to synthesis by J. (Exercise 9). 


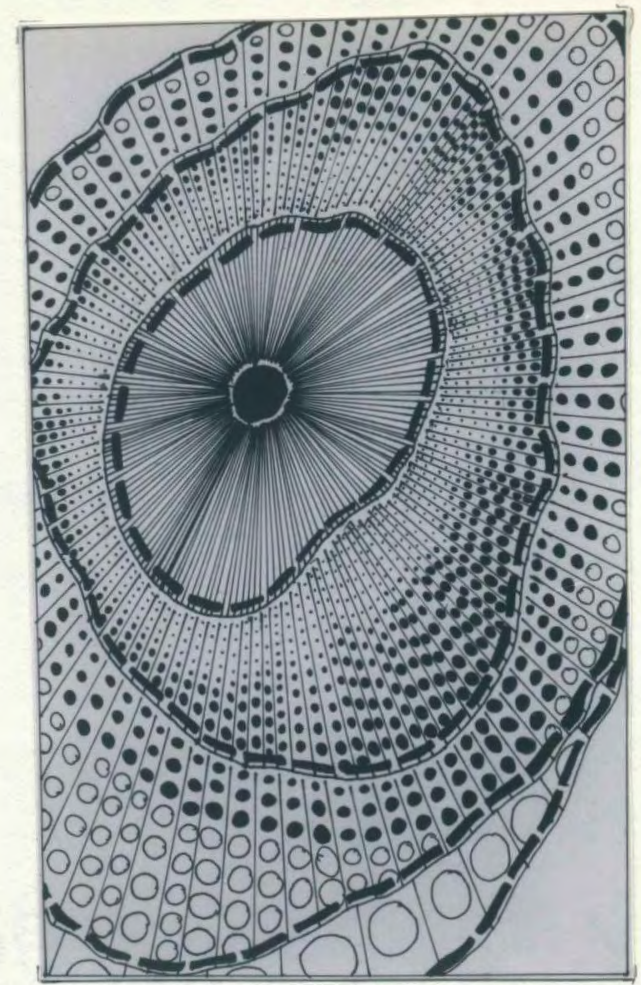

FIGURE 28. Finished "synthesis" by B. (Exercise 9).

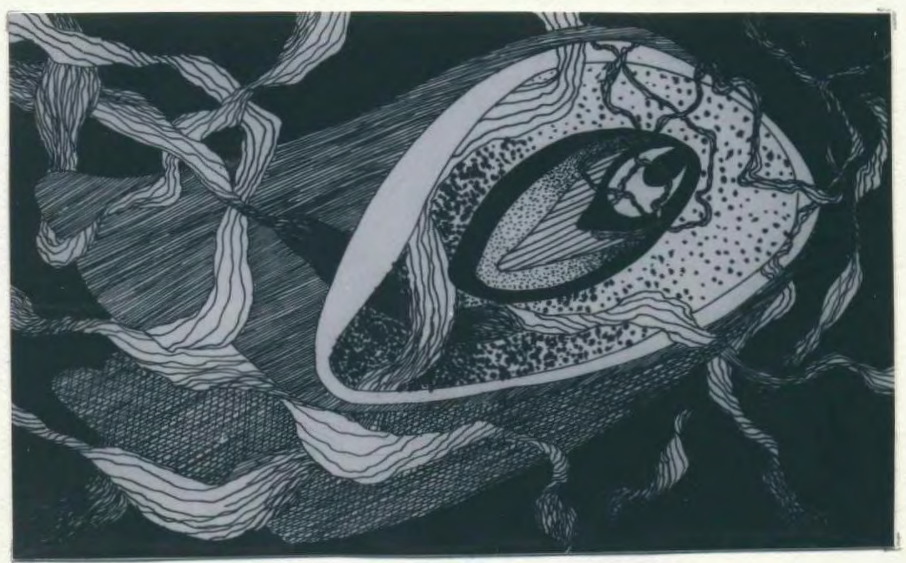

FIGURE 29. Finished "synthesis" by L. (Exercise 9). 


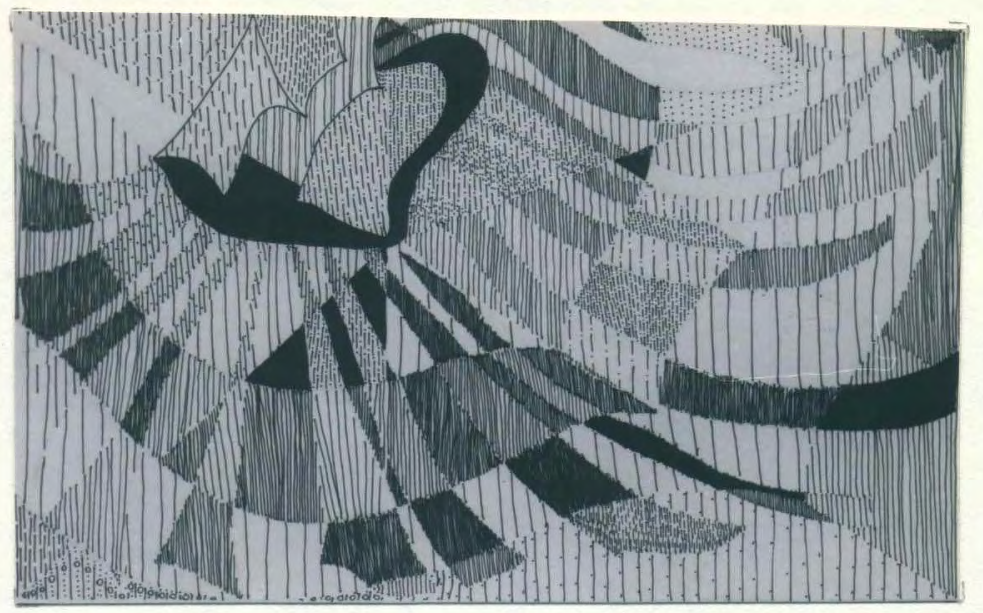

$$
\begin{aligned}
& \text { FIGURE 30. Finished "synthesis" by D. } \\
& \text { (Exercise 9). }
\end{aligned}
$$

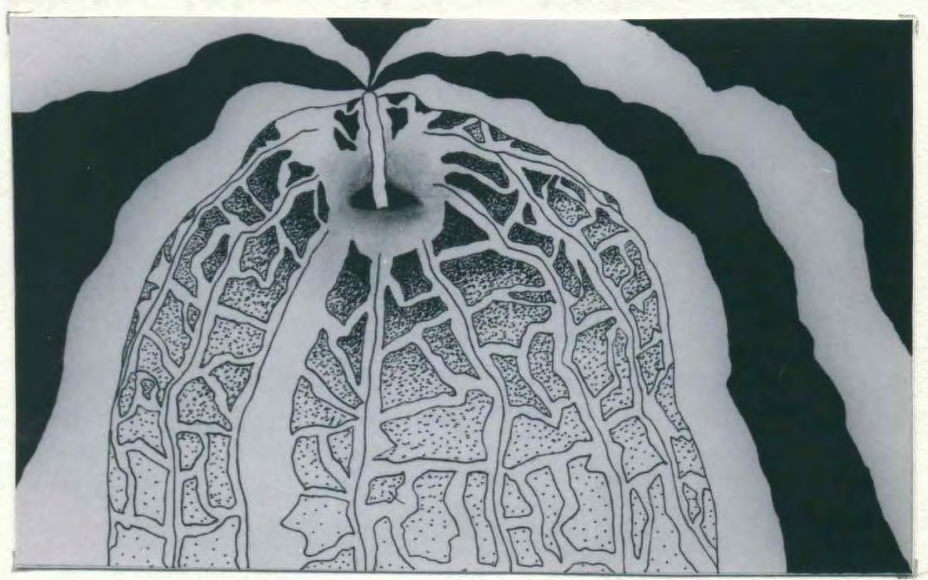

FIGURE 31. Finished "synthesis" by J. (Exercise 9). 
(figures 25a and 25b) Describing the word "abstract" in a similar way, another student explained, "I learned to simplify and to add my own shapes where they were needed. That was hard for me because I always try to work with what I see only, but once I got the hang of it!..." (figure 29). The student concluded her comment with a statement demonstrating her understanding of Bevlin's definition of design, quoted earlier. The student wrote, "It isn't the details that are important as much as the general design and rhythm that the details combine to form." Finally, another student implied that his more complete understanding resulted from the particular terminology presented ("analytic" to "synthetic"). He wrote, "I tried to incorporate same of the [microscopic] viewing levels into the completed design (synthesis) at once." The parentheses around "synthesis" are his own. His description of this synthesis included a concern to "1) Incorporate the cell structure and use this pattern to get graduated light/dark patterns; (figure 27a) 2) Emphasize the basic shape of the pepper [his subject matter] ...; and 3) Keep the logarithmic curve noticeable." He recalled this third component from our earlier discussion of the Fibonacci series. This discussion had shown how the logarithmic curve is based on the dimensions inherent in a golden rectangle, (52) the dimension specified for each design. The resulting design (figure 27b) is not only attractive, but a very successful accomplishment in terms of his and my objectives.

In concluding this exercise, I was aware that the mechanics of this process had been complex and, perhaps, too rigid for the (52) Dendel, p. 42. 
sensibility of same artists and art educators. At the same time one cannot overlook what appears to have been a meaningful learning experience to general education students.

EXERCISE 10 - Art And Language

Baudelaire poetically referred to an important link between art and language in his statement, "nature is only a dictionary." The statement implies that it is "the artist's task to constitute a creation - a poem -" out of the words which nature provides. (53) since the time of Baudelaire, artists and critics have been attermting to form a synthetic language - unique to the visual arts - a "language where not the words, but their context and their relations are of the utmost importance." (54) My interest in these ideas has resulted in an attempt to create art problems which link art and language. Part of this interest also developed from some of my own art, which I developed in my graduate studio work. In it I attempted to use words directly in the art image to evoke visual thoughts, an idea related to "visual thinking."

I was able to find less research material directly related to my rationale for this exercise. Perhaps this is because art functions and language functions are contained in characteristically different brain hemispheres. Nevertheless, some educators are presenting ways to

(53) H.L.C. Jaffe', "Syntactical Structure in the Visual Arts," Structure in Art and in Science, Gyorgy Kepes, ed. (New York: George Braziller, 1965), p. 137.

(54) Ibid., p. 137. 
enrich instruction by employing, simultaneously, these seeningly opposite kinds of "language." Elizabeth Stull offered interesting insights in an article called "Drawing a Story and Listening to a Picture: A Verbal/Visual Relationship." She concludes that "the syntactical structure of verbal language may help same children to structure a visually coherent drawing." (55)

Bertrand Russell said, "I believe that partly by means of the study of syntax we can arrive at considerable knowledge concerning the structure of the world." (56) Perhaps the Chinese had this understanding ages ago when they developed a structural system for writing the characters of their language. Chinese children, for instance, still learn to write each character on a grid of nine squares, and "each part of the character touches one of the nine squares." Apparently, this structure was "employed as the most useful" aid in developing symmetrical balance, (57) a visual skill. All of this suggests, perhaps, a link, in the perceptual realm, between art and language. 'In fact, the terms 'inflexion' and 'declension' derive etymologically from 'bending,' thus revealing their perceptual origin." (58) Figure 32 is a visual illustration of this perceptual

(55) Elizabeth Crosby Stull, "Drawing a Story and Listening to a Picture: a Visual/Verbal Relationship," Arts and Activities, Vol. 90, no. 5 (January 1982), p. 46.

(56) Gyorgy Kepes, Structure in Art and in Science (New York: George Braziller, 1965), p. iii.

(57) Rand, p. 161.

(58) Arnheim, "Visual Thinking," p. 12. 
link. It also represents a visual/verbal problem I have assigned to students in the past, with generally successful results. The problem is to design a word with appropriate letters, the appearance of which non-verbally communicate the word's meaning. I mention this example also because I recently discovered a book, wORDS by Mark Soppeland, which consists completely of similar visual/verbal images. Soppeland describes the problem-almost identical to mine-which he has assigned to students in design courses since 1975. "Words are seldam contemplated as words... [rather] vehicles of communication and imagery." (59)

These ideas were among my thoughts when I developed exercise 10 in group B. As in the previous exercise, it was presented as an approach toward understanding cognitively the creative, visualizing process. To this end, a list of verbs served as tools to interpret personally selected subject matter in unique ways. Each student selected one verb fram the following list as the context for interpreting their subject: magnify, minify, rearrange, alter, adapt, modify, substitute, reverse, combine. Thus, a verbal thought was intended to be the motivator in the imaging process. This list was originated by Alex Osborn, the inventor of brainstorming, and appears in the book, The Universal Traveler, as a method of widening perceptions when developing ideas. (60)

(59) Mark Soppeland, WORDS (LOS Altos, CA: William Kaufmann, Inc., 1980), p. v.

(60) Don Koberg and Jim Bagnall, The Universal Traveler (Los Altos, CA: William Kaufmann, Inc., 1972), p. 69. 
Because this was presented as the final project in the course, students were allowed to mix other two-dimensional, black and white media with pen and ink. They were encouraged to use what visual skills they had acquired to represent their idea.

Again, students' responses, visual and verbal, reflected their insight relating the link between art and language to the process of design. Among these responses, two related comparisons can be drawn fram the illustrations in figures 33-36, which also provide same interesting conclusions about the "skills" and "motives" approaches discussed in chapter 2.

The first comparison concerns figures 33 and 34 , representing works created by different students. Both students used the verb "magnify" to interpret their respective subject matters. The image in figure 33 represents a rather literal interpretation of the verb. In her drawing of the instamatic camera, the student employed her samewhat awkward ability with linear perspective, a skill which she learned before taking the design course. I underlined the word "skill" because it relates to one of the teaching approaches discussed earlier. Her perceptual interpretation draws more heavily on her "skill" than upon her "motive," which explains her more literal interpretation of the word magnify. The other student shows less ability with visual "skill" and more perception in her "motive." (figure 34) Actually, this example represents simultaneous interpretations of two words. The student later wrote, the words "magnify and minify were intriguing to me, and I thought of combining the two to cause each other." This is a simple, yet thought-provoking explanation of the visual relationship (metaphor) she discovered between the wrench handle and a magnifying glass, a 


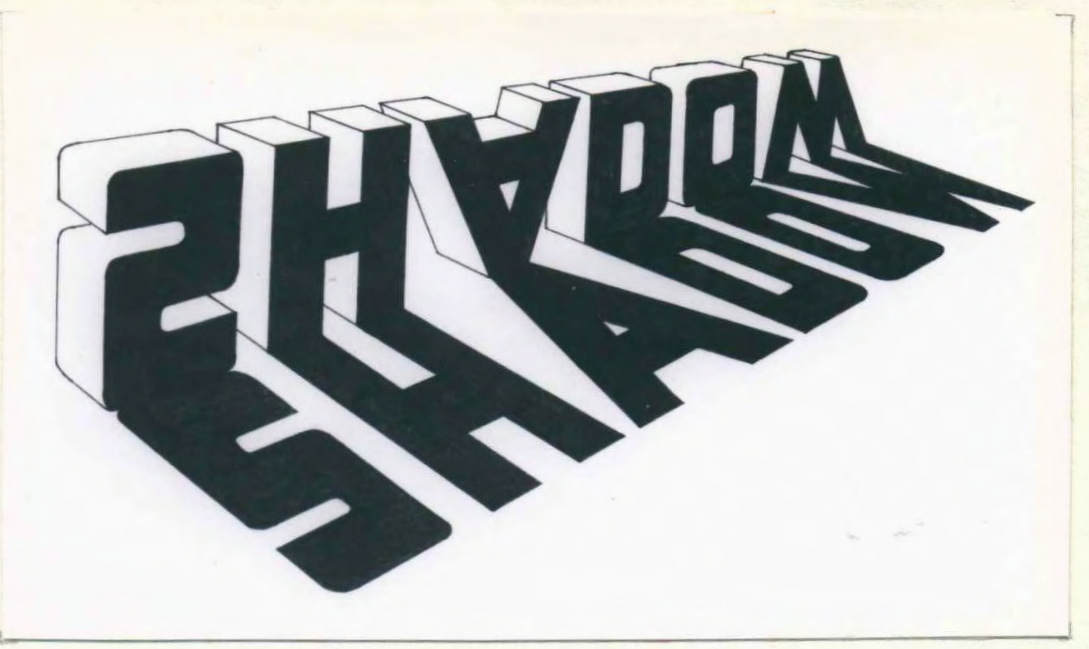

FIGURE 32. Visual/verba1 illustration by author.

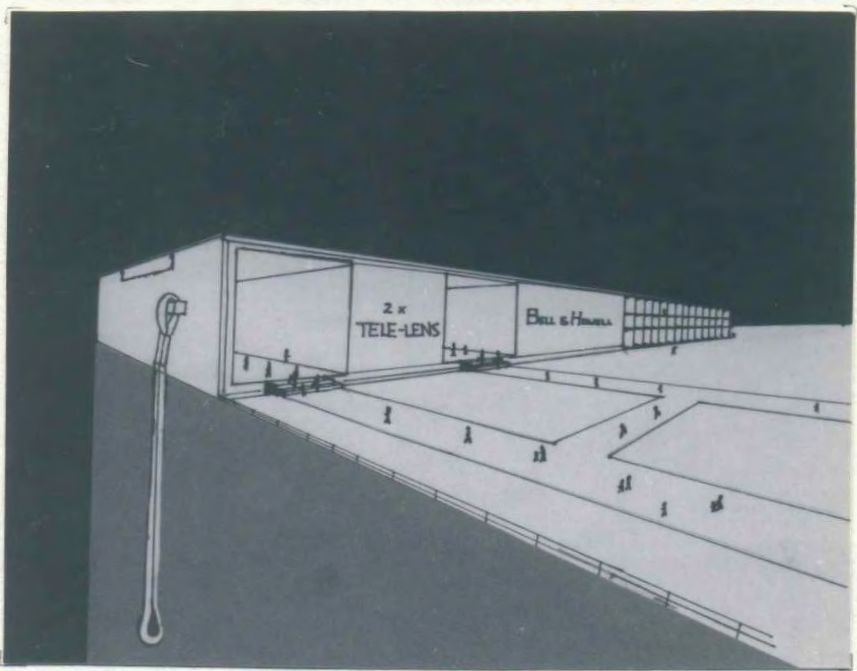

FIGURE 33. "Magnify" interpreted by S. (Exercise 10).

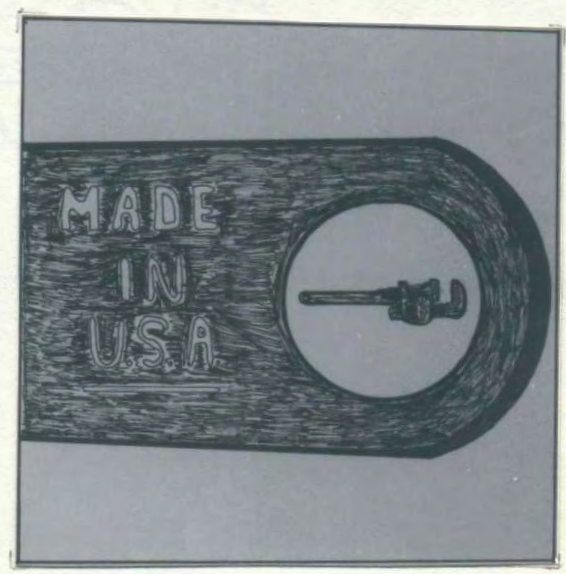

FIGURE 34. "Magnify/Minify" interpreted by C. (Exercise 10). 
relationship she used perceptively to achieve her goal. The relationship might never have been seen were it not for the verbal component which initiated her interpretation of the wrench. Although the workmanship is of lesser quality than the first example, it is an insightful interpretation, providing a fuller understanding of the words which evoked it and a good example of the "motives" approach to problem-solving.

A similar comparison can be made in figures 35 and 36 . These works were also done by different students who each interpreted their various subject matters with the word "adapt." As in the first comparison, one is a more literal interpretation with a skilled execution (figure 35). The chain on the post in the right-hand corner is literally "adapted" to the changing background, which was arbitrarily divided into three sections. The student reported that it was a good opportunity "to experiment with a variety of design elements and combine them." Though the illustration in figure 36 is not lacking in technical skill, this example is a fuller, relational interpretation of the same verb. Not everyone will understand how this image was interpreted from the word "adapt;" one must understand the context in which it was created. The student's subject matter was a computer terminal, on which is superimposed the image of a cornerstone, representing Concordia college's first administration building. When this building was demolished the cornerstone was saved and is now centrally located in the center mall of the campus. The design then, is a dramatic symbol of how concordia has "adapted" itself to a new age; its first mini-computer was installed only a year ago. Again, it seems very apparent that the "verbal cue" was a cognitive influence in 


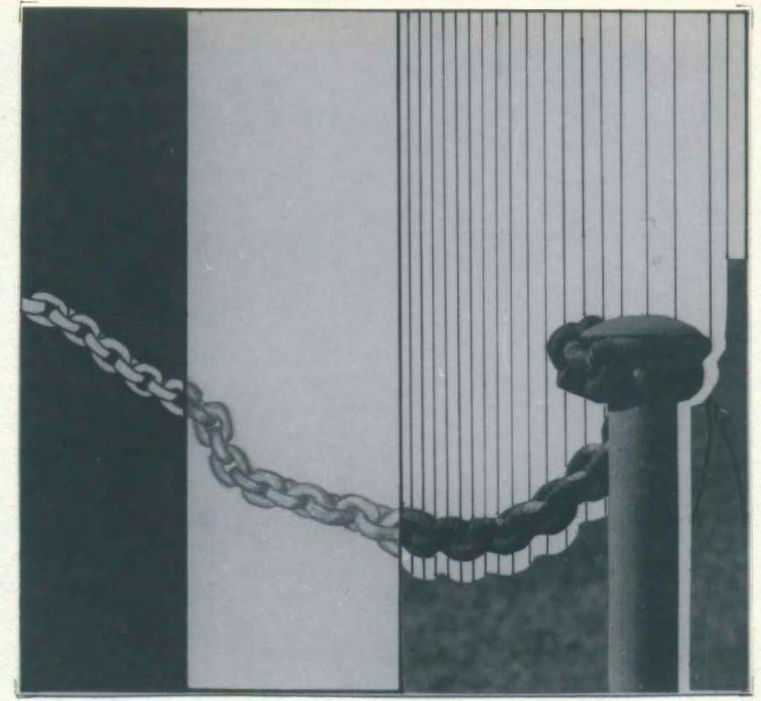

FIGURE 35. "Adapt" interpreted by M. (Exercise 10).

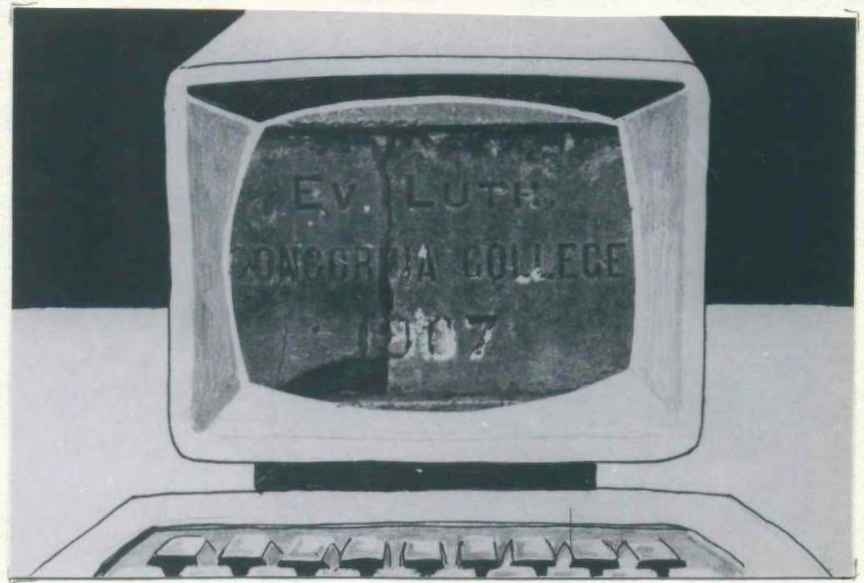

FIGURE 36. "Adapt" interpreted by J. (Exercise 10). 
the design choices, suggesting that language and imagery were interrelating in that process.

Some students did not respond to the format for this exercise, indicating, for example, that it was easier to create images about their subject and later assign an appropriate verb. One can only speculate whether other verbal thoughts influenced these cases. At any rate, several students expressed their enriched understanding of the creative process. One student remarked "Art visualizes language," expressing her perception of the relationship. The statement, however, is debatable, since visualization can occur on levels which go beyond language. On that note, one student said (tongue in cheek) "a picture is worth a thousand words." 
CHAPTER V

\section{CONCLUSIONS}

It is fitting that the last illustration in this thesis is an image representing a part of concordia. I began this document with a specific reference to Concordia, the context in which my goal developed, and the illustration in figure 36 is a fine indication that my goal was achieved.

I believe the format I used was a significant factor toward achieving my goal. Even though "art is the perfect marriage of psychic impulse and technical implementation," as quoted earlier, dividing these two aspects made for an effective method for teaching and understanding the cognitive processes of art. The skill-oriented exercises presented in chapter 3 addressed the component of technical implementation, while the integrative exercises in chapter 4 addressed the component which Argïelles called psychic impulse. Teaching these two groups in the order presented was also beneficial, because students were able to respond with more confidence to group B after building a workable visual vocabulary in group A. I suspect that fewer educators would challenge the ideas and approaches used in group A. Group B, however, might cause more doubt and confrontation. Some might suggest that the art process is diluted when it is taught in conjunction with other disciplines. I would agree only insofar as the interdisciplinary approach is not the only way art should be taught. That is why the group A exercises were included, providing visual organizational skills 
as a balance to the more relational content in group B. And since "art education has to be re-evaluated in the broader context of visual thinking," (61) the approach proposed here offers a step toward accomplishing that process. Furthermore, relating art and its processes to other disciplines improves a person's ability to see relationships not normally expressed. In an age when fragmentation and disorientation is affecting our culture, such a process can be a vehicle of continuity, when presented effectively. This I have attempted to do.

As to my original goal, I believe the students' comments, and their work, give evidence that their visual awareness has increased and that they understand some integral relationships between art and science and between art and language. same student comments might suggest how this experience has helped their general education. Students were asked at the beginning and the end of the course to consider how the visual awareness exercises might affect their everyday experience. At the end of the term, there were same who had not made the connection, making me wonder if the teaching was ineffective or if, perhaps, the lives of these students have been so fragmented that they no longer understand the real purpose of education (that is, to prepare oneself for life). Other students were enthusiastic about the experience. "It has made me be more conscious of decision-making regarding options and limitations. I used to think of limitations in a negative way. But now I can really see their usefulness, and the

(61) Gyorgy Kepes, ed., Education of Vision (New York: George Braziller, Inc., 1965), p. v. 
freedom they allow. Almost like a paradox: limitations/freedom." Finally, the science major who had been my personal challenge, as her instructor, wrote, "at first I saw no connection. However, now I can see the need for analysis and creativity in both design of art, and in design of scientific study." The exercises had provided her with a note of continuity. 
Argïelles, Jose. The Transformative Vision. Boulder, $\infty .$, Shambhala Publications, 1975.

Arnheim, Rudolf. "Perceiving, Thinking, Forming." Art Education. March 1983.

Arnheim, Rudolf. "Visual Thinking." Education of Vision, Gyorgy Kepes, ed. New York, George Braziller, Inc., 1965.

Ballinger, Louise and Vroman, Thomas. Design: Sources and Resources. New York, Reinhold Pub. Corp., 1965.

Basset, Richard, Ed. The Open Eye in Learning. Cambridge, Mass., The MIT Press, 1969.

Bevlin, Marjorie Elliot. Design Through Discovery, brief ed. New York, Holt, Reinhart and winston, 1980.

Bronowski, Jacob. "The Discovery of Form." Structure in Art and in Science, Gyorgy Kepes, ed. New York, George Braziller, Inc., 1965.

Cassidy, Harold. The Sciences and the Arts: A New Alliance. New York, Harper and Brothers, 1962.

Chipp, Herschel B. Theories of Modern Art. Berkeley, CA, Univ. of Calif. Press, 1968.

Commoner, Barry. The Closing Circle. New York, Bantam Books, 1971.

Dendel, Esther Warner. Designing Fram Nature: A Source Book for Artists and Craftsmen. New York, Taplinger Pub. Co., 1978.

Edwards, Betty. Drawing on the Right Side of the Brain. Los Angeles, J.P. Tarcher, Inc., 1979.

Eisner, Elliot W. "On the Relationship of Conception to Representation." Art Education. March 1983.

Engel, Martin. "Art and the Mind." Art Education. March 1983.

Gardner, Helen. Art Through the Ages, 6th ed. New York, Harcourt Brace Jovanovich, Inc., 1975. 
Goodman, Nelson. "Notes from the Underground." Art Education. March 1983.

Hofstadter, Douglas R. Gödel, Escher, Bach: An Eternal Golden Braid. New York, Random House, 1979.

Holton, Gerald. "Conveying Science by Visual Presentation." Education of Vision, Gyorgy Kepes, ed. New York, George Braziller, Inc., 1965.

Hunter, Madeline. "Right-Brained Kids in Left-Brained Schools." Today's Education. Nov.-Dec. 1976.

Jaffe', H.L.C. "Syntactic Structure in the Visual Arts." Structure in Art and in Science, Gyorgy Kepes, ed. New York, George Braziller, Inc., 1965.

Jensen, Hans. Sign Symbol and Script. 3rd rev. ed. London, Allen and Unvuin, 1970 .

Kandinsky, Wassily. "On the Problem of Form." The Blaue Reiter Almanac. New York, Viking Press, 1917.

Keiler, Manfred L. The Art in Teaching Art. Lincoln, NE, Univ. of Nebraska Press, 1961.

Kepes, Gyorgy, Ed. Education of Vision. New York, George Braziller, Inc., 1965.

Kepes, Gyorgy, Ed. Structure in Art and in Science. New York, George Braziller, Inc., 1965.

Koberg, Don and Bagnall, Jim. The Universal Traveler. Los Altos, Calif., William Kaufmann, Inc., 1972.

Lancaster, Peter. Mathematics Models of the Real World. Engelwood Cliffs, New Jersey, Prentice-Hall, Inc., 1976.

Lowenfeld, Viktor and Brittain, Lambert. Creative and Mental Growth, 6th ed. New York, Macmillan Pub. Co., Inc., 1975.

McKim, Robert. Experiences in Visual Thinking. Belmont, CA, Wadsworth Pub. Co., 1972.

Rand, Paul. "Design and the Play Instinct." Education of Vision, Gyorgy Kepes, ed. New York, George Braziller, Inc., 1965.

Read, Herbert. Education Through Art, 3rd ed. New York, Random House, 1958.

Samples, Bob. The Metaphor ic Mind. Reading, Mass., Addison-Wesley Pub. Co., 1976. 
Samples, Bob, Charles, Cheryl, and Barnhart, Dick. The Wholeschool Book. Reading, Mass., Addison-Wesley Pub. Co., 1977.

Sausmarez de, Maurice. Basic design: the dynamics of visual form.

New York, Reinhold Pub. Corp., 1964.

Soppeland, Mark, et. al. WORDS. Los Altos, Calif., William Kaufmann, Inc., 1980.

Stull, Elizabeth Crosby. "Drawing a Story and Listening to a Picture: A Visual/Verbal Relationship." Arts Activities. January 1982.

Toben, Bob and Wolf, Fred Alan. Space-Time and Beyond, new ed. New York, E.P. Dutton, Inc., 1982.

Waddington, C.H. Behind Appearance: A Study of the Relations Between Painting and the Natural Sciences. Edinburgh, University Press, 1969.

Weismann, Donald L. Language and Visual Form: The Personal Record of a Dual Creative Process. Austin, Univ. of Texas Press, 1968.

Wolfe, Tom. The Painted Word. New York, Farrar, Straus and Giroux, 1975.

Wong, Wucius. Principles of Two-Dimensional Design. Van Nostrand Reinhold Co., 1972.

Zukav, Gary. The Dancing Wu Li Masters. New York, Bantan Books, 1979. 